\title{
JOAN PALOU, FOUNDRYMAN AND MASTER CANNON MAKER OF THE CITY OF BARCELONA AT THE END OF THE $15^{\text {TH }}$ CENTURY $^{1}$
}

\author{
Luisa Amenós Martínez \\ Catedral de Barcelona \\ SPAIN
}

Date of receipt: $31^{\text {st }}$ of August, 2018

Date of acceptance: $6^{\text {th }}$ of May, 2019

\section{Abstract}

In the Late Middle Ages, artillery became a key element of military tactics. Monarchy, nobility and government institutions were aware of the need to employ the services of craftsmen specialised in the art of building, repairing and using firearms.

This study analyses the working and professional reality of these craftsmen using the biography of the Barcelona foundryman and cannon maker, Joan Palou. The numerous written sources located in the Historical Archive of the City and in the Archive of Notarial Protocols, have made it possible to trace a detailed portrait of his professional activity - and thus, of the first cannon makers - in the early days of artillery making. The inventory of his widow's goods, made in 1526 and transcribed at the end of the article, offers a detailed description of the craftsman's workshop and his work tools, of his personal property and real estate and of the documentary archive he kept in a corner of his house.

\section{KeYWORDS}

Artillery, Bronze, Foundrymen, Cannon makers, Craftsmen, Barcelona, Middle Ages.

\section{CApitalia Verba}

Artilleria, Aes, Fabri ferrarii, Fabricatores cannonum, Artifices, Barcino, Medium Aevum. 
Catalan historiography, and Hispanic historiography in general, has devoted little attention to the study of copper-based metal crafts. In spite of recognising the importance of this area in the research of medieval culture and society, the works published until today are scarce and often offer a fragmentary view. The archaeological excavations carried out in the last thirty years have made it possible to document a good number of medieval structures related to copper metallurgy. ${ }^{2}$ At the same time, medievalist historians have published a considerable corpus of documents related to the activity ${ }^{3}$ and to the objects produced by coppersmiths -mainly bells ${ }^{4}$ and pieces of artillery. ${ }^{5}$

The study also draws on written sources and its main objective is to delve into one of the least known craftsmen collectives of medieval Barcelona.

1. In thanks for the support of Dr. Nicolas Thomas (INRAP - LAMOP Université Paris 1 Pantheón, Sorbonne), scientific advisor for this study. Used Abbreviations: ACB, Arxiu Capitular de Barcelona; AHCB, Arxiu Històric de la Ciutat de Barcelona; AHPB, Arxiu Històric de Protocols Notarials de Barcelona.

2. One of the first studies on the subject was published by Sancho, Marta; Caballé, Antoni; Pujades, Josep. "Les restes arqueològiques d'un forn de bronze d'època medieval de la Seu de Manresa". Acta Historica et Archaeologica.

Mediaevalia, 11-12 (1991): 485-493. After that date other metal ovens have been found in archaeological excavations. Most of which are cited in the following publications: Tribuna d'Arqueologia. Barcelona: Generalitat de Catalunya, 1983-2011; Congrés d'Arqueologia Medieval i Moderna de Catalunya. Associació Catalana per a la Recerca en Arqueologia Medieval, 1998, 2002, 2008, 2010, 2014, 2018; Quaderns d'història de la ciutat de Barcelona. Barcelona: Museu d'Història de la Ciutat de Barcelona, 2005-2018; Jornades d'Arqueologia de les comarques de Girona. Girona: Universitat de Girona, 1992-2018.

3. Amenós, Lluïsa. "Copper artisans in Barcelona (XIV to XVI century): Approached through written sources", Medieval copper, bronze and brass. History, archaeology and archaeometry of the production of brass, bronze and other copper alloy objects in medieval Europe (12 $2^{\text {th }}-16^{\text {th }}$ centuries). Namur: Agence Wallonne du Patrimoine, 2018: 141-153; Amenós, Lluïsa. “'Confraria fabrorum Barchinone': l'organització dels oficis relacionats amb la indústria derivada del ferro a la Barcelona baixmedieval", Els Gremis a Barcelona. Barcelona: Arxiu Històric de la Ciutat - Institut de Cultura, 2018: 223-235; Córdoba de la Llave, Ricardo. "Las artes del fuego: metalúrgia y alfarería", Ars Mecanicae. Ingeniería medieval en España. Madrid: Ministerio de Fomento, CEDEX-CEHOPU, 2008: 203-210; Riu de Martin, M. Carmen. “Caldereros barceloneses de la primera mitar del siglo XV". Acta Historica et Archxologica Medixvalia, 31 (2011-2013): 393-422.

4. The reader will find a good bibliographic complication in: Camós Cabruja, Lluís. “Dietari de l'obra del rellotge i la campana del castell de Perpinyà l'any 1356", Homentage a Antoni Rubió i Lluch. Barcelona: without publisher, 1936: III, 423-446; Argilés i Aluja, Caterina. "El rellotge medieval de la Seu Vella de Lleida". Acta Historica et Archaeologica Mediaevalia, 14-15 (1993-1994): 259-273; Casals Parladé, Judit. "Les campanes i el rellotge de la Catedral de Vic". Ausa, 16 (1995): 195-222; Padilla Lapuente, José Ignacio. "Las campanas horarias de la catedral de Lleida: hacia una nueva cesura del tiempo urbano (s. XV)", Congrés de la Seu Vella de Lleida. Actes. Lleida: Pagès Editors, 1991: 159-166.

5. Artillery production has not been a great point of interest among Catalan historians. See: Gudiol i Cunill, Josep. "D'artilleria catalana antiga II". La Veu de Catalunya, 10 September 1914: 6; Ferrer Mallol, Maria Teresa. "La organización militar en Cataluña. Siglos XII al XV". Revista de Historia Militar, 45 (2001): 191-193; Sobrequés i Callicó, Jaume. La guerra civil catalana del segle XV, 1: Causes i desenvolupament de la crisi. Barcelona: Edicions 62, 1987. 


\section{Courers, cannon makers, bellfounders: Coppersmiths in the Middle Ages}

In the late Middle Ages, artillery became a key element of military tactics: ballestes de tro ("crossbows"), bombards, culverins, blowguns, falconets or passavolants ("small poweful cannons") are frequently cited in late medieval Catalan documentation.

Aware of the strategic value of the arms industry, government institutions promoted specific policies to control and stimulate the metallurgy industry and enacted a series of privileges and tax concessions designed to benefit the transforming industry: for example, the exemption from taxes on ironworks used in the construction of galleys (1367), the components of swords and crossbows (1370), and the construction of bombards (1397). ${ }^{6}$

Monarchy, nobility and government institutions were made aware of the need for the services of craftsmen specialised in the art of building, repairing and using firearms. The Diputació del General de Catalunya and the City Council of Barcelona had their own cannon maker at least since the mid- $14^{\text {th }}$ century. The first craftsmen to carry out the job were blacksmiths. However, in the mid-fifteenth century, and as a result of the development of bronze artillery, the appointment of blacksmiths decreases in favour of foundrymen.

The main mission of the cannon maker of the General Council was to build and maintain the necessary artillery for the royal army service. ${ }^{7}$ The municipal artillery maker, however, alternated the role of cannon maker with other roles within his trade. Thus, in addition to artillery work, locksmiths and foundrymen took orders designed to meet the daily needs of buildings managed by the municipality, the city mint or the public network of water sources, canals and ditches. Although the municipal cannon makers were not entitled to a salary, the position guaranteed them a stable source of income and permanent contact with the most important institutions in the city. Iron artillery was a specialty of blacksmiths, and bronze was that of the courers ("coppersmiths") or buydadors ("casters"), craftsmen specialised in the casting techniques of copper-based metals. ${ }^{8}$ Bronze, which is lighter, more flexible and more resistant to corrosion than iron, offered better safety features, as it did not explode into shrapnel. In addition, its manufacturing process, based on moulding and seriation, was much more agile and permitted a better response to production demands during periods of war.

Despite the diversity of trades associated with metallurgy of copper, the sector was divided into two large groups determined by the size of the products manufactured and, consequently, by the capacity of their workshops. Foundrymen producing

6. Duran i Sanpere, Agustí. “La documentació del Col·legi de Mestres Manyans, Armers i Agullers de Barcelona". Recull de Documents $i$ Estudis, 1 (1920): 75-76.

7. The accounts book of the Generalitat de Catalunya states that their mission was to produce bombardes, buçons, colobrines e totes altres coses de coure qui fossen necessàries al dit General ("bombards, battering rams, culverins and other copper things necessary to this general"). Dietaris de la Generalitat de Catalunya. Barcelona: Generalitat de Catalunya, 1994: I, 158.

8. Amenós, Lluïsa. “Copper artisans in Barcelona... ": 141-153. 
small objects had limited infrastructure and a small number of tools. Within this group were the freners ("makers of equestrian equipment"), quincallers ("makers of personal adornments, button-makers, thimble-makers"), the guaspers ("ferrule makers"), the sivellers ("manufacturers of buckles and ornamental appliques"), etc. They tended to unionise with the freners, with whom they shared common needs, such as their close relationships with the leather craftsmen.

Unlike these craftsmen, the cannon makers and bellfounders required greater technical specialisation and an infrastructure suitable for the casting of large pieces. Their catalogue of products ranged from artillery pieces, bells and architectural components such as large doors and gates, to furniture, sculptures, mortars, candelabras or taps. They were associated with the Confraria fabrorum Barchinone, a guild corporation born in 1380 in response to the needs of the various trades related to the iron industry. ${ }^{9}$ Foundrymen producing large pieces had to maintain union links with the blacksmiths for professional and fiscal reasons if we remember that, since 1397, they had the royal privilege that granted tax exemption to cannon makers.

Bronze cannon makers also appear to be associated with the manufacture of watches and hydraulic devices. For example, Bernat Vidal, creator of the first mechanical clock in the city of Barcelona and various hydraulic devices for the Estany del Port, the irrigation canal (Rec Comtal) and the orchard of the Royal Palace. Upon his death, which occurred around 1473, the king himself praised his practical skills: les arts mecàniques que ell entre d'altres cultivà. ${ }^{10}$ This comment clearly illustrates the respect that medieval society had for the cannon makers' knowledge and their technical skills and that, although they never obtained the status of liberal art, they did enjoy the privileged status granted by scientia and ingenium.

The casting of cannons in Barcelona was carried out outdoors, in open spaces or spaces that belonged to the city: we know, for example, that in 1486 Aloy Roca prepared the casting of a new bombard in the botiga ("warehouse") of Sant Daniel, near the Pla d'En Lull. The city had an arsenal in the Shipyard, with a bombarderia for the storage of numerous pieces of iron and bronze artillery that we know of through an inventory made in $1465 .{ }^{11}$ We have knowledge of the fact that, on the $18^{\text {th }}$ of August 1509, another bombard was cast en un hort del costat del studi (refering to the university or Estudi General), prop del portal de Sanct Sever. ${ }^{12}$ This space could be located in what is currently Rambla dels Estudis, in the section close to Plaça Catalunya and Carrer Pelai. In the year 1518, the Councillors of the City decided to buy the aforementioned site in Pla d'en Llull to use it as a park or artillery depot. ${ }^{13}$

\footnotetext{
9. Amenós, Lluïsa. “'Confraria fabrorum Barchinone'... ": 224-225.

10. "the mechanical arts which, among others, he cultivated". Vinyoles i Vidal, Teresa M. "Bernat Vidal, rellotger i 'enginyer' barceloní del segle XV". Acta Historica et Archaeologica Mediaevalia, 23-24 (2002): 612. 11. Carreras Candi, Francesc. "Les Dreçanes barcelonines, sos inventaris y restauració". Butlletí del Centre Excursionista de Catalunya, 38/392 (1928): 23-24.

12. "in an orchard next to the Studio [General], near the Saint Sever entrance". Gudiol i Cunill, Josep. “D'artilleria catalana antiga...": 6.

13. AHCB. Fons Municipals. Registre de Deliberacions (01.12.1516-27.11.1518), f. 36v, 39, 77v.
} 
At the beginning of the $16^{\text {th }}$ century, the municipal government became aware of the need to equip itself with infrastructures and personnel specialised in the manufacture and maintenance of artillery. ${ }^{14}$ The first earnings of master artillery makers are documented around 1532, but it is between 1540 and 1560 that the number of such payments increase as a result of the opening of the School of Artillery of Barcelona: ${ }^{15}$ on July $30^{\text {th }}$ 1551, After his entry into the collective of artillery craftmen, the foundry worker, Antoni Fenodi, sold all his tools and ammunition to Emperor Charles V, ${ }^{16}$ and in 1578, the municipal council discussed building a foundry and an arsenal in front of the shipyard, near the city wall . The foundry was finally located in the current Rambla de Sant Josep, near the Porta Ferrissa entrance, in a warehouse built by the master builder, Jaume Brufal. ${ }^{17}$

\section{The master foundryman, Joan Palou}

Joan Palou came from a long line of coppersmiths that were active in Barcelona at least from the late fourteenth century. The documentation discovered so far gives us data of four individuals dedicated to this same profession and probably related to the same family unit, although it is difficult to establish the degree of kinship. The first of them is the bellfounder Pere Palou, creator of the Honorata bell of the Barcelona Cathedral, installed in the Torre de les Hores in the year $1393 .{ }^{18}$ The second is Dalmau Palou, documented between 1433 and 1434 due to the casting and installation of the bell in Santa María de Mediona Church. ${ }^{19}$

In 1440 it is noted that the master bell and bombard founder, Bartomeu Palou, worked for the city of Barcelona ${ }^{20}$ and on February $4^{\text {th }} 1461$, after the death of Mateu de L'Om, he was named Bombarder del General. ${ }^{21}$ In the accounts book of the

14. Medina y Ávila, Carlos J. "De la Escuela a la Academia. Los centros de formación de artilleros". Revista de Historia Militar, Extra 1 (2014): 26.

15. AHCB. Fons Municipals. Registre de Deliberacions (30.11.1530 - 27.11.1532), f. 200.

16. Amenós, Lluïsa. “Antoni Fenodi, maestro artillero de la Ciudad de Barcelona", in preparation.

17. Gudiol i Cunill, Josep. “D'artilleria catalana antiga... ": 6.

18. Carreras Candi, Francesc. "Las obras de la Catedral de Barcelona. 1298-1445". Boletín de la Real Academia de Buenas Letras, 50 (1913-1914): 130.

19. The bell was installed on May $14^{\text {th }}, 1434$. Mas i Domènech, Josep. Notes històriques del bisbat de Barcelona, Barcelona: tip. J. Vives, 1906: I, 112-113 (appendices 1 and 2).

20. Vinyoles i Vidal, Teresa M. “Bernat Vidal, rellotger... ": 605, n. 20.

21. In 1404, the master bellfounder of Barcelona, Mateu de l'Olm, requested residence in the town of Cervera for a period of twenty years, but cancelled it in 1427, claiming he wanted to return to Barcelona. However, he continues to appear in the documentation from Cervera until the middle of the $15^{\text {th }}$ century. In the year 1424, he made the bell called $\mathrm{Na}$ Talons d'Ase for the church of Santa Maria de Cervera. On October $9^{\text {th }}, 1424$, he signed pacts with Pere Safont to make two bells for the same church, which are still preserved: the main bell and the Carranca. Both depict a heraldic shield centered by an om ("elm"), which has been associated with this master craftsman. The first bell bears a legend that says: Matheus de Olmo, magister cimballorum, villae Cervariae, me fecit anno nativitate Domini millesimo quadringentesimo vicesimo 
Generalitat de Catalunya - former Diputació del General — it specifies that his job was to create the artillery. ${ }^{22}$

In 1425, a Joan Palou is documented in Vic (hereinafter Joan Palou I), together with a cimbaler ("bellfounder") from Barcelona, called Pere Safont, in relation to an order of various copper pots by the coppersmith, Rodrigo de Calatayud, from Vic. ${ }^{23}$ The following year he is documented again under the same concept, but this time with the bellfounder, Mateu Nol. ${ }^{24}$ Most probably, his presence in Vic can be associated with the production of a bell. ${ }^{25}$

In 1460 we hear of Joan Palou again, related this time to the death of the painter Jaume Vergós I. The friendship between the Palou and the Vergós families is evident in the inventory of the deceased painter's property, made on July $29^{\text {th }}, 1460$. In it, a figure of San Miguel is registered that belonged to Palou, lo courer. ${ }^{26}$

Jaume Vergós, father and son, held the title of painters of flags and shields of the Consell de Cent (Council of One Hundred) and worked in close collaboration with the Palous and other craftsmen linked to the municipality and the great buildings of the city. In 1473, they worked together on the production of a new head for the equestrian figure of Sant Jordi which presided over the first fountain of the cloister of the Cathedral: the goldsmith Berenguer Palou was commissioned to design it, Joan Palou to cast it and Jaume Vergós II to gild it. ${ }^{27}$ Palou had previously worked for the Cathedral: On November $9^{\text {th }}, 1462$, He received 1 lliura and 6 sous for casting four copper taps to the same fountain. ${ }^{28}$ According to chronology, the Palou documented on this occasion would correspond to a generation younger than that registered in Vic and could be our protagonist.

quarto. Llobet i Portella, Josep Maria. "Les campanes de l'ésglésia Santa Maria de Cervera". Miscel-lània Cerverina, 16 (2003): 72-73 (doc. No. 16-19).

22. Dietaris de la Generalitat...: 158.

23. Riu de Martin, M. Carmen. "Caldereros barceloneses... ": 413-414, n. 59 and 60.

24. Safont signed the pacts to produce two bells for the church of Santa Maria de Cervera. Between 1431 and 1432, he produced another one for the cathedral of Vic, together with the cannon maker, Bartomeu Ferran. The latter worked on the bells of Santa Maria de Besora (1438), the seny of the lladre of the Cathedral of Vic (1459) together with his son-in-law, Joan de Tres Nichs- and the bell of the castle of Calafell (1462). His activity as a cannon maker runs parallel to the Civil War: we know that between the years 1462 and 1464 he sold a total of 19 bombards and blowguns.to the municipality. On August $8^{\text {th }}$, 1463, he founded a copper bombard, baptized with the name of Santa Eulàlia, in an esplanade near the old Shipyard and on January $10^{\text {th }}, 1475$, he created another one for King Juan II. See: Casals i Parladé, Judit. "Les campanes i el rellotge... ": 195-222. Gudiol i Cunill, Josep. “D'artilleria catalana antiga... ": 6. Sobrequés i Callicó, Jaume. La guerra civil catalana...: 248.

25. The acquisition of copper vessels shortly before founding a bell is documented, for example, in the cathedral of Barcelona or in the parish church of Bagà. Santandreu Soler, M. Dolors. "La construcció del seny major de Bagà". L'Erol, 42 (1993): 18.

26. The inventory of the property of the painter Jaume Vergós I was published by Duran i Sanpere, Agustí. Barcelona i la seva Història. Barcelona: Curial, 1975: III, 193, n. 7.

27. Amenós Martínez, Lluïsa. “L'activitat dels ferrers a la Seu de Barcelona entre el darrer terç del segle XIV i finals del segle XV". Estudis Històrics y Documents dels Arxius de Protocols, 25 (2007): 73. Amenós Martínez, Lluïsa. "Catàleg de ferrers documentats en les fonts escrites d'època medieval". Butlletí Arqueològic de la Reial Sociedad Arqueologica Tarraconense, 29 (2007): 114.

28. ACB. Obreria. Llibre de l'Obra (1461-1463), f. 149v. 
Joan Palou was an active member of the blacksmiths' corporation in Barcelona: in 1477 he was listed as levador de l'almoyna of the Portal Nou, the neighbourhood where he lived. ${ }^{29}$ Los llevadors de l'almoina were in charge of managing the ordinary accounts of the entity and were elected annually by all the members.

At the end of the $15^{\text {th }}$ century, Palou appears working in the main buildings of the city. We know for example that he cast numerous taps for public fountains for the monastery of Pedralbes, which was under the direct protection of the Consell de Cent (Council of One Hundred) by order of Queen Elisenda de Montcada. On October $22^{\text {nd }}, 1491$, the master founder charged various amounts for gunpowder and taps per me facte ad opus fontum dicte Civitas, in addition to twenty sous for three axetarum cupri per sortidor. ${ }^{30}$ On July $27^{\text {th }} 1499$ we find documented once more, payment for two taps for the monastery of Pedralbes: one for the vegetable garden and another for the abbess. ${ }^{31}$ On December $23^{\text {rd }}$ of that same year he received 1 lliura, 7 diners and 8 sous for casting various copper objects, among which is a bell that, according to the manuscript, the nuns usually rang when someone entered the convent. ${ }^{32}$

\subsection{Working as a master bellfounder}

Bellfounding is one of Joan Palou's best documented activities. On October $5^{\text {th }}$, 1486, this craftsman and the priest, Pere Ferrer, signed to cast the bell for the church of Sant Llorens d'Hortons. ${ }^{33}$ The same day, he received 10 lliures from Barcelona as pro rata payment and first payment of the total of 30 pounds agreed.

Almost ten years later, on May $30^{\text {th }}, 1495$, he signed another contract for the casting of a new bell for the missing temple of Sant Pere d'Octavià, located in the municipality of Sant Cugat del Vallès (see Annex 4.1.1). ${ }^{34}$ The jurats ("municipal magistrates") Antoni Canals and Pere Saguera, and the worker Bartomeu Vilar acted in representation of the parish. The foundryman promised to cut the old bell and take it down from the bell tower and the representatives of the parish to move it to his workshop in Barcelona, with the aim of reusing the bronze in the new bell..$^{35}$

It was stipulated that the new bell would have a weight equal to or greater than the old one and its cost would amount to 16 Barcelona lliures ("pounds"). If the new one exceeded the weight of the former bell, the representatives of the parish would

29. AHCB. Fons gremials: Serrallers. Llibre Major de la Confraria de Sant Eloi, f. 89 (payroll of 1477). 30. AHCB. Fons municipals: Obreria. Àpoques d'obreria de la Ciutat (1485-1492), f. 46r-46v.

31. Santjust Latorre, Cristina. L'obra del Reial Monestir de Santa Maria de Pedralbes des de la seva fundació fins al segle XVI. Barcelona: Universitat de Barcelona (PhD Dissertation), 2009: 793 (Annex).

32. Santjust Latorre, Cristina. L'obra del Reial Monestir...: 793.

33. AHPB. Notari Galceran Balaguer. Lligall, 25; Manual, 20 (1486-1487), f. 17.

34. AHPB. Notari Lluis Carles Mir. Llibre comú (1495), f. 142v, 143r, 143v.

35. The recasting of old or broken bells is documented on numerous occasions. In Catalonia, we have examples in the church of Bagá (1383), in the church of Santa Maria de Cervera (1385) or in the Cathedral of Lleida (late $14^{\text {th }}$ century). See. n. 21 and 24. 
bear the costs of two Barcelona sous per pound. If, on the other hand, it weighed less, the bellfounder would return the difference at the price of one sou per pound.

The installation of the new bell must have been carried out between the months of June and July of 1495, setting a six-month warranty to check its proper working order. Should it prove defective, two master bellfounders would be appointed, one representing each party, to ensure its quality and Palou promised to cast it as many times as necessary until the contracting party were satisfied. The fine for breach of the pacts was set at twenty-five Barcelona pounds.

Written sources document the creation of a third bell for the monastery of Sant Llorenç del Munt, an agreement for which was signed on June $21^{\text {st }}, 1503 .{ }^{36}$ The historian Josep Gudiol attributed the creation of a fourth bell to the bellfounder in 1511, destined for the Barcelona basilica of Santa María del Mar, although this fact seems doubtful (see the next section).

\subsection{The position of cannon maker and coppersmith of the city}

On November $27^{\text {th }}$ of 1492 , Palou took on the position of cannon maker and courer of the city of Barcelona. The Board's Book of Deliberations registers his appointment: En lo que es demanat per en Johan Palou, courer, en esser bombarder e courer de la Ciutat, lo dit Consell, attanent que lo dit Palou es persona ydonea e sufficient per als dits exercicis lo elegí en dits officis, sens salari algu que per acò no li sia per la Ciutat donat. ${ }^{37}$

The position included the privilege of having the job assured for life, although without an assigned salary. Before his appointment, Palou had received municipal commissions related to the manufacture of "gunpowder and ammunition" (pilotes de bombarda): thus, on September $17^{\text {th }}, 1491$, he charged 3 Barcelona pounds for half a hundredweight of gunpowder destined for the city's bombards. ${ }^{38}$ On February $11^{\text {th }}$ of the following year he was paid several amounts for gunpowder for the new bombards, as well as motllos de coure per fer pilotes, pilotes de plom and some passavolants nous. ${ }^{39}$

Throughout the year 1491, the city acquired several pieces of artillery, among which are two iron bombards made for the feast of Corpus Christi, the payment for which was ordered on April $27^{\text {th }} 1492$, after checking its working order. ${ }^{40}$ On the $26^{\text {th }}$ of November of the same year, Palou received the quantity of 23 lliures, 2 sous and 2 diners owed for motlos per ffer pedras de plom per los pasa volans, e poliges per lo rey delles ores, pedras e manechs fets per los dits pasa volans. E per II quintars de polvora

36. AHPB. Notari Pere Pasqual. Lligall, 1; Manual, 40 (1503), f. 28v.

37. "what is requested for Johan Palou, coppersmith, being a bombardier and a coppersmith of the City, this Council, considering that Palou is a suitable and sufficient person for such exercises, elected him for these offices, without any salary". AHCB. Fons municipals. Registre de Deliberacions, 31, f. 66r.

38. AHCB. Fons municipals: Obreria. Àpoques d'obreria de la Ciutat (1485-1492), f. 46r.

39. "copper moulds for making balls", "lead balls" and some new passavolants". AHCB. Fons municipals: Obreria. Àpoques d'obreria de la Ciutat (1485-1492), f. 49r.

40. AHCB. Fons Municipals. Registre de Deliberacions, 31, f. 27v. 
venuda a la dita Ciutat, per les alimares ffetes per.la entrade dels senyors Rey, Reyna e del primogenit en la present Ciutat. ${ }^{41}$ This last appointment refers to the visit made by the Catholic Monarchs on October $24^{\text {th }}, 1492$, accompanied by their children. ${ }^{42}$ The city organized a great welcome celebration, as was customary in these cases, and commissioned the foundryman to make the festive luminaria lights and the trons of bombards and passavolants.

On August 23 $3^{\text {rd }}, 1502$, as a result of the deficiencies detected in the defence of the city, the Council discussed the need to renew artillery: Item hi fou proposat, com ells Consellers veent que la Ciutat stave en molta fretura de artellaria per defenslo sua, lo que portave gran derreputacio e vergonya a aquella per no poder se defendre dels enemics e piratas qui acostumen venir en la plage de les mars de la dita Ciutat, y amen pençat que fos feta tanta quanta seria necessaria per satisfer a la dita necessitat lo que ells no podien fer sens deliberació del present Consell (...). ${ }^{43}$ That same year, the City Council named a new coppersmith, Pere Soler. ${ }^{4}$ Palou was freed from these roles and went on to concentrate solely on artillery jobs. Between 1503 and 1504, he founded and tested a new bombard for the city: on October 22nd 1504 , the municipal clavari (treasurer) authorized the payment of 20 lliures and 8 sous for gunpowder de ell comprada a obs de sperimentar la bombarda grossa novament feta a obs de la dita ciutat and for dos jornals a messos per la dita ciutat en lo esperiment fet de la dita bombarda. ${ }^{45}$

Palou have passed away on 1506: as it is stated that the $23^{\text {rd }}$ of February fou proposat com lo offici de courer e bombarder, vacana de present, per mort den Johan Palou, ultim possehidor de aquell. ${ }^{46}$ I should point out, however, that the historian Josep Gudiol documents a Joan Palou in 1511, on the occasion of the creation of a bell for Santa María del Mar, although this data has not yet been confirmed. ${ }^{47}$

\footnotetext{
41. "moulds to make lead stones for the passavolant, and pulleys for the 'king of the hours', stones and handles for the passavolants. And for II quintals of gunpowder sold to the City, for the campfire made for the entrance of the King, the Queen and the firstborn into the City". AHCB. Fons municipals. Clavaria, 110, f. 206r.

42. Rúbriques de Bruniquer. Ceremonial dels Magnífics Consellers i Regiment de la ciutat de Barcelona. Barcelona: Impr. d'Henric, 1912: I, 265.

43. "it was proposed, as the Councillors saw that the City needed artillery to defend it, which entailed lack of reputation and shame in not being able to defend itself from the enemies and pirates who used to come to the beach and the seas of this City, that so much be done as is necessary to satisfy this need, which they could not do without the deliberation of the present Council". AHCB. Fons Municipals. Registre de Deliberacions, 36, f. 38r .

44. AHCB. Fons Municipals. Registre de Deliberacions, 36, f. 35v.

45. "bought by him to experience the big bombard - cannon- made for the City" and for "two days spent on the experiment made on that bombard". AHCB. Fons municipals. Clavaria, 124, f. 182r.

46. "was proposed for the coppersmith and bombardier craft, now vacant for the Johan Palou death, the last holder". AHCB. Fons Municipals. Registre de Deliberacions, 38, f. 23v.

47. Gudiol i Cunill, Josep. Nocions d'Arqueologia Sagrada Catalana. Vic: Impremta Balmesiana, 1933: II, 501.
} 


\section{The house and workshop of Joan Palou seen through his widow's inventory (1526)}

After Joan Palou died, all the properties belonging to the married couple became the property of the widow, Joana, who passed away at the beginning of the year 1526. The inventory of their goods was carried out between March $27^{\text {th }}$ and May $26^{\text {th }}$ of that same year, and public auction was held in the Lonja de Mar between April $11^{\text {th }}$ and June $1^{\text {st }}$ (see transcript in Annex 4.1.2). The document, kept in the section of Notarial Protocols of the Historical Archive of the City of Barcelona (AHCB), is a paper notebook consisting of 36 double-sided manuscripts. It has been maintained in good condition, although small losses are observed produced by biological agents currently inactive. The text, written over various days by the notary public Joan Palomeres, is divided into three parts: the first corresponds to the inventory of the personal property kept in the house-workshop that the couple had in Carrer de la Capilla de Marcús; the second, to the inventory of goods of the houses located near the Plaza de la Vila Nova, called les fusines ("foundries"); the third part corresponds to the public auction accounts.

The inventories occupy the first 22 pages. They are headed by a legal paragraph, written in Latin, followed by the property register written in Catalan. This is divided into chapters organised according to the different spaces that existed within the inventoried properties, headed by the corresponding title. The text, written in ink, presents some marginal and interlining deletions and annotations. The public auction is stipulated from page 23 and, unlike the inventory, it is organised by days. The contents are distributed into two columns that are arranged vertically: one on the left, for the registration of goods, and another on the right, reserved for economic valuation. This is divided into lliures, sous and diners and has the corresponding total sum at the end of each page. Between pages 25 and 26, a sheet is kept, dated October $30^{\text {th }}, 1527$, where the fees of the notary public Joan Palomeres are broken down.

The buyers of the auctioned goods were mainly from Barcelona, except for three of them from Aragón, Valencia and Mallorca, respectively. They were professionals of different sectors (see Annex 4.2): there are eight metallurgical craftsmen, seven ecclesiastics, four notaries, three brokers, two apothecaries, two carpenters, two tailors, two peasant farmer, a wool carder, a wool weaver, a squire, a nursemaid, a painter, a baker, a paller and a sailor. Among the metal craftsmen, there are three blacksmiths, two scrap merchants, a goldsmith, a cannon maker and a hardware dealer who lived or had the workshop in front of the Lonja. And among the ecclesiastics, we find a friar of the disappeared convent of Carmen and the vicar of the basilica of Santa María del Pi.

The apothecary, Joan Solsona received the economic profit of the auction and allocated a part to pay for the works that the foundryman Antoni Rubio had carried out in the chapel of Marcús. The nursemaid, Tomassa Garcia, received 15 lliures, 8 sous and 10 diners for the 40 pounds of copper and the 59 pounds of brass she had advanced, at a rate of 15 diners per pound of copper and 14 diners per pound of 
brass. These facts lead us to believe that the workshop must have remained active after the death of Palou and remained perhaps under the responsibility of the aforementioned Antoni Rubio.

Joana's inventory of goods allows us to get a closer look at the working, social and economic reality of a Barcelona foundryman at the end of the $15^{\text {th }}$ century, through a detailed description of his real estate, his work tools and the personal property that he owned. The text also includes a complete list of the documentary archive that the craftsman kept in his Marcús house, the study of which provides various pieces of information regarding his working life and his personal and professional relationships.

\subsection{Property and real estate}

As we have already said, the Palou couple owned two properties: their main place of residence, located on the Carrer de la capella d'en Marcús-according to the fogatge of 1497 (book that recorded payment of tax for each house)-, ${ }^{48}$ and another home called les fusines (illustration 1). The latter was located close to El Born, in an area away from the town centre known as Vilanova de la Mar. The term fusina ("foundry") evokes the image of a place or workshop where metals are founded ${ }^{49}$ and its memory still survives in the toponymy of Barcelona today. The house-workshop near the chapel of Marcús was typical of Barcelona workingclass housing: it was divided into a ground floor and two upper floors, connected vertically by a staircase. The lower floor accommodated the workshop, the pastador ("dough kneading room") and the storage spaces; the first floor was intended for housing and the second floor housed the chicken coop, the attic and other rooms ${ }^{50}$

The access from the street was through two doors that gave way to a hall or lobby. Near it, in an unspecified location, was the pastador ("dough kneading

48. Iglésies, Josep. El fogatge de 1497: estudi i transcripció. Barcelona: Rafael Dalmau, 1992: I, 134.

49. (...) degun payroler (...) no gos fondre ni fer lurs fusines (...)(“no coppersmith (...) dares to melt or to make foundry"). Coromines, Joan. Diccionari etimològic i complementari de la llengua catalana. Barcelona: Curial, 1980-1991: IV, 88 (doc. No. 1372).

50. Although there are many published works on medieval domestic spaces, I shall cite just a few illustrative titles: Batlle, Carme. "La casa i l'obrador de Pere Sanglada, mestre d'imatges de Barcelona (+ 1408)". D'Art, 19 (1993): 85-96. Batlle, Carme. “La família i la casa d'un draper de Barcelona, Burget de Banyeres (primera meitat del segle XIII)". Acta Historica et Archaeologica Mediaevalia, 2 (1981): 69-91. Batlle Gallart, Carme. Vinyoles i Vidal, Teresa M.. Mirada a la Barcelona medieval des de les finestres gòtiques. Barcelona: Rafael Dalmau editor, 2002. Bolós, Jordi. La vida quotidiana a Catalunya a l'època medieval. Barcelona: Edicions 62, 2000: 186-189. Roca, Josep Maria. “Un cirurgià barber (Leonci Mestre, 1437) Barcelonès de la XV centúria". Boletín de la Real Academia de Buenas Letras de Barcelona, 10-11 (19211924): 145-162. Sabaté i Curull, Flocel. "Els objectes de la vida quotidiana a les llars barcelonines al començament del segle XIV". Anuario de Estudios Medievales, 20 (1990): 53-108. Vinyoles i Vidal, Teresa. "El espacio doméstico y los objetos cotidianos en la Cataluña medieval". La casa medieval en la península ibérica. Madrid: Sílex, 2015: 613-650. Vinyoles i Vidal, Teresa. “Inventari i encant dels béns de Berenguer Abella, esmolet, al carrer de Sant Cugat del Rec, any 1388". Cuadernos de Historia Económica de Cataluña, 15 (1976): 9-50. 


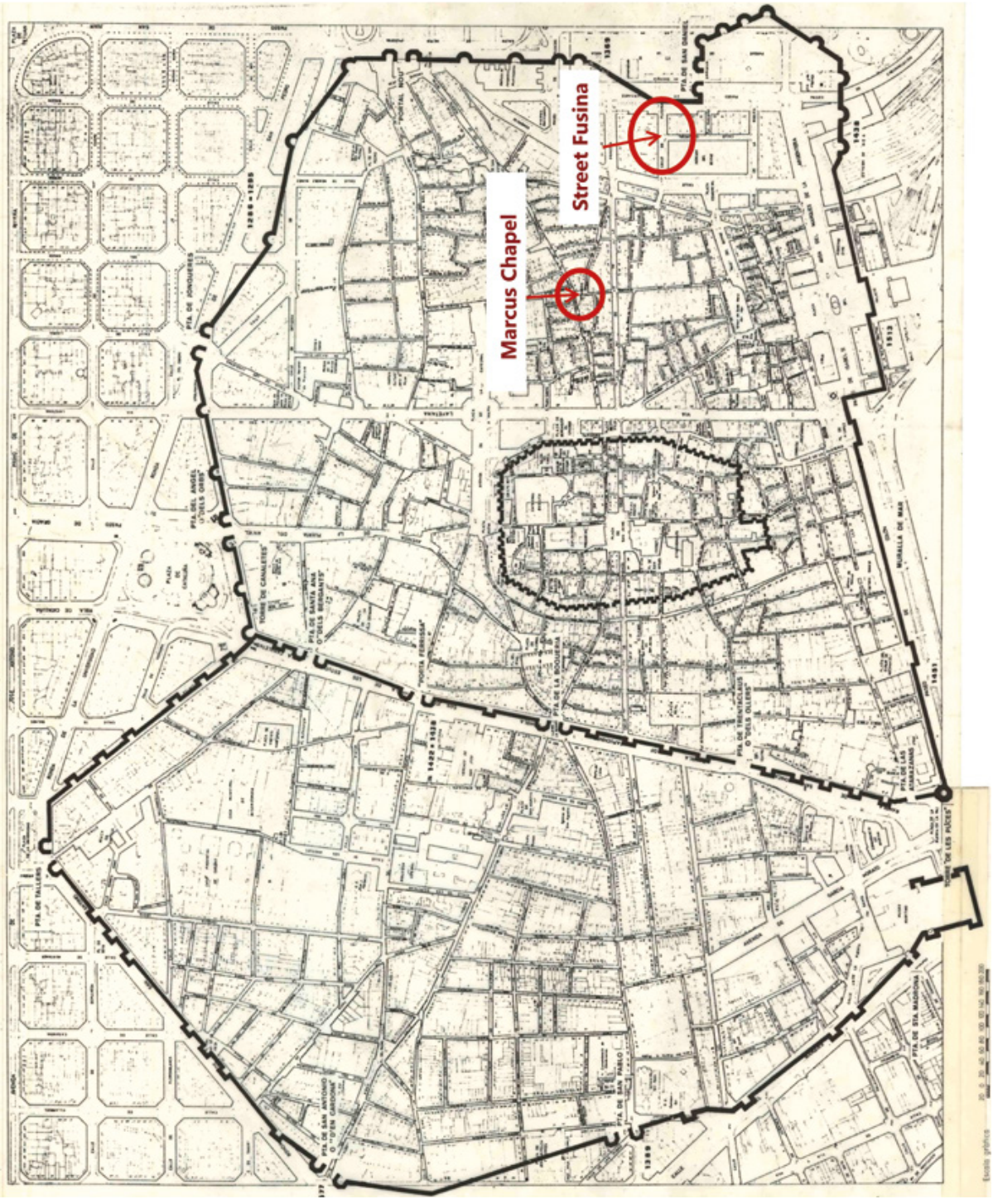

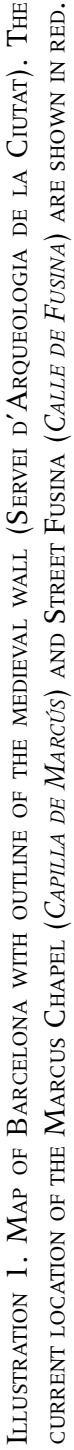


room"), a space that, judging by the inventoried objects, was used as a cellar. On the same ground floor two porches or galleries are registered. Although the text does not allow us to identify its architectural structure or its exact location, the word porch evokes the idea of the arcaded gallery of an interior courtyard that would be located in the central or rear part of the dwelling, a common element in medieval Barcelona's domestic architecture. ${ }^{51}$

The home consisted of a kitchen, a living-dining room, a cambra major ("large chamber"), a smaller one and a retret de la recambra ("slightly set back third one"). The text does not allow us to interpret the layout of these spaces, but it is possible to think that they would follow the typical criteria of Mediterranean houses: that is, they would be articulated around a central room (the living-dining room). The second floor was organized around two chambers, one of which lead to a chicken coop. It was the brightest, thanks to the light that came through a window that faced the street. It must have been used as a warehouse as there are various wooden boxes and a large jug with a hundredweight of white beans, to make clocks, registered inside it. It should be noted, in this regard, that the inventory records various ampoules ("recipients") for hourglasses.

The lobby on the ground floor was presided over by a large bronze bell, of about 3 hundredweights, next to a wooden table and various boxes and cabinets where tools of the trade and copper objects of all kinds were kept (candelabras, taps, bells, ornamental appliques...). The bell could be put in relation with the work that the foundryman, Antoni Rubio, was doing at that time in the chapel of Marcús, and that they are mentioned in public auction.

At the entrance of the house there were, among many other utensils, various pieces of artillery: two small falconets, some mascles of copper, recambres de bombardes ("bombar chambers") and 25 pairs of copper moulds to buydar pedres de artillaria ("cast round shots"). Half a barrel of salpetre ("nitre in its natural state") and a bag of refined nitre are also documented. Inside a cupboard, he kept a wooden pastera per pastar ("kneading tool") with gunpowder and, in the attic, protected from the damp, he stored two baskets full of gunpowder destined for this same type of weapon.

The pastador ("dough kneading room") was dominated by a lliurador ("measurer or charger"), a piece of wood furniture traditionally used to knead flour. In this case, it was used to knead the clay with which they made the moulds and templates for the pieces to be cast. Among the various objects documented in this space, we find una scopeta de coure ab·la guarnicio de fust ("a copper shotgun with a wooden hilt") and a large quantity of copper objects: barrels, tubs, buckets, pots, basins, cauldrons, etc. The text does not clarify if they were pieces in use or recently manufactured and stored for sale.

On one of the porches, numerous tools and pieces of equipment are documented that can be associated with a metal casting furnace. The inventory registers a fornell ("iron furnace") to cast metals, with its pulley, medium sized bellows ab dos canyons

51. Graus, Ramon. "El gros de l'obra a les cases: parets, sostres i cobertes abans i a partir de la industrialització". Les Arts aplicades a Barcelona. Barcelona: Àmbit-Ajuntament de Barcelona, 2018: 28-29. 
de ferro, abtes per manxar als fornals de fonre metals ("with two iron cannons, suitable for blowing into the furnaces of melting metals"), five large iron tongs abtes per traure los cresols del fornell ("suitable for taking the crucibles out of the furnace"), five iron bars abtes per atiar al foc per.al offici de courer ("suitable to stoke the fire for the craft of coppersmith") and fourteen iron hooks abtes per als mollos de buydar ("suitable for casting moulds").

The second porch was reserved for drilling, turning and filing of the cast pieces. Among other tools documented, we also find a large gimlet, five turning irons, an anvil and a wooden bench with its screw, used to file the cast products. Also registered are a large number of wooden and clay moulds to cast pieces of artillery.

The furniture of the house was mostly made of wood and was typical of a craftsman's home of this period: mainly the ironed finished boxes, wardrobes, folding tables, chairs and stools. The living room featured a large table, with its chairs, and a tinell ("wooden sideboard") where the luxury tableware was displayed. It would probably have been placed at the top of the stairs, as can be seen in the few examples that have survived to this day. ${ }^{52}$ The presence of a chessboard, accompanied by their respective pieces and mats, leads us to think that the Palou's standard of living must have been quite comfortable.

Inside the boxes and wardrobes all kinds of pieces of clothing and household objects were stored, mixed with foundry tools and valuable objects — such as a figure of Jesus and four silver spoons stored in their respective cases. In the dining room there was a box with ceramic and wooden foundry moulds and in the attic another with broken crucibles. The large chamber, or bedroom, featured a llit encaixat ("fitted bed") made of poplar wood, painted in yellow, provided with a paillasse and three mattresses full of Sardinian wool. The chests that surrounded it contained the deceased woman's most prized possessions: 36 pearls of medium size, two ring stones that had not been set, various psalms books, a Book of Hours of parchment and a leather case, in the form of a booklet, with a weight and some slabs to write on. Inside a cupboard, there were two bottles full of aigua nafa ("orange blossom water") and rose water that Joana must have used to perfume the room. The inventory also records curtains decorated with plant motifs.

The small bedroom also had a fitted bed. The furniture was completed by a large brass candelabra with six arms, a chest of poplar wood and a couple of altarpieces with the representation of the Virgin and the Lord. The chest contained sheets, pillowcases and various pieces of clothing along with wooden patterns to cast letters, kept in a white bag. In a drawer of the same piece of furniture, patterns for seals and mortar ribbing, two jambinets and various copper pieces are recorded.

The Palou's kitchen had two wooden shelves with a large copper pitcher. Among the wide variety of copper and brass pots, there were iron objects typical of medieval kitchens, such as grills, stoves or spits. There are also two copper fogons de jueu ("hearth of Jew"), one of them with two feet.

\footnotetext{
52. Pascual i Miró, Eva. “Els tinells, les taules i els seients", L'art gòtic a Catalunya. 8: Les arts de l'objecte. Barcelona: Enciclopèdia Catalana, 2008: 320.
} 
The staircase that connected to the first and second floors gave access to two chambers, located on the left, and a large room on the right. It had a large bed, covered by a bed cover decorated with the shield of Aragon and crowned by a canopy of black curtains bordered in white. The furniture was completed by some arquibancs ("storage benches"), various iron-finished boxes filled with clothing and a poplar wood platform covered with coloured rugs. ${ }^{53}$ An altarpiece with an image of the virgin and baby Jesus was hung on the wall, surrounded by other figures. As with the rest of the house, the chests in the master bedroom kept all kinds of objects related to the craft of metal casting: cambines, taps, saucepans, bells, moulds...

The Palou's kept their archive on a landing on the staircase, on the section that connected the first and second floors (See specific section). The documents shared the space with two jugs filled with olives and various patterns of bells and figures made with lead.

The Palous were owners of a second property: the so-called houses of Les Fusines or Vila Nova. The plural name could make us think of a group of houses of a single body subdivided or annexed by the same owner, a custom that appears documented in medieval Barcelona. ${ }^{54}$ The les Fusines houses were entirely used as an artillery workshop. This assumption is supported by the presence of gunpowder and tools related to the manufacture of firearms.

The house of Vila Nova consisted of a ground floor and one upper floor. It was accessed via an entrance that gave way to two botigues ("spaces") of different sizes. Documented in them are various moulds to cast copper pots and bells, as well as two bellows with their respective nozzles: one large and the other medium de fornal de argenter ("goldsmith's forge"). The text does not clarify whether the large bellows were associated with a forge or a melting furnace.

Next to the entrance was the botiga xica ("small shop -or store-"), where products manufactured in the workshop were sold. This is confirmed by the board that I understand to be arranged as a counter. The botiga gran ("large shop -or store-"), next to the previous one, contained a lot of tools of the trade. The presence of a mill and two stone mortars used to grind and chop gunpowder, proves the industrial use of those spaces as gunpowder mills and artillery workshops. This is confirmed by the numerous boxes filled with gun and cannon powder, located in different corners of the house, along with sacks of coal and sofre vert de cano ("green cannon sulfre"). The gunpowder was stored in wooden barrels or in ceramic glazed pots to protect it from the damp.

The first floor of les fusines was divided into three spaces: a porch or gallery, a dining room, located above the botiga xica, and a third adjacent chamber. In the dining room there were various tools related to the forge and foundry: iron clamps to extract the crucibles from the fornal ("forge — or furnace-"), a small anvil, a large set of Roman scales accompanied by lead weights, a saw and four irons to stoke the fire.

53. The estrada was a typical place in houses on the peninsula reserved for female social life. Commonly linked to the bedroom, they consisted of a wooden platform covered with rugs and furnished with seats and cushions. Rodríguez Bernís, Sofía. "El mueble medieval", Mueble español: estrado y dormitorio. Madrid: Comunidad de Madrid, Consejería de Cultura, 1990: 42-47.

54. Graus, Ramon. "El gros de l'obra... ": 29. 


\subsection{The archive}

Joana's inventory refers to the documentary archive that the Palou couple kept in their Marcús house (see Annex 4.3). It was basically composed of testaments, property documents, cens and accounting books related to the activity of the workshop. The types of documents recorded are the following:

- 10 books of delivery notes, 7 large ones and 12 small notebooks. The chronological interval of these documents spans the entire $15^{\text {th }}$ century, which leads us to suppose that the oldest ones correspond to the professional activity of Joan Palou I and the later ones to that of Joan Palou.

- Copies of wills, inheritances and testamentary transfers.

- Notary documents related to the purchase / sale of real estate, especially the house located in Vila Nova.

- Cens paid for the Vila Nova house between 1525 and 1526, with an explicit list of the amounts corresponding to the last receipts. Among these documents is the Libre dels cens de la fusina.

In the accounting books, Palou recorded all the settlements related to the economic activity of the workshop, that is to say, the expenses related to the purchase / sale of metals and the payments and / or debts. Complex and long-term commissions, such as the casting of a piece of artillery or a bell, required high technical training, a planned accounting strategy and strict control of economic management. For this, the craftsman opened a workbook where he recorded every detail from the acquisition of material to the payment of the various craftsmen who were involved in the project (smelters, blacksmiths, carpenters, rope makers...). A good example of this is the workbook for the clock and the bell of the castle of Perpignan, written in the year 1356 and currently preserved in the Archive of the Crown of Aragon. ${ }^{55}$ Joan

Palou kept a book of accounts in his archive starting in September 1497, in which there is a reference to the abbot of Sant Llorenç, without

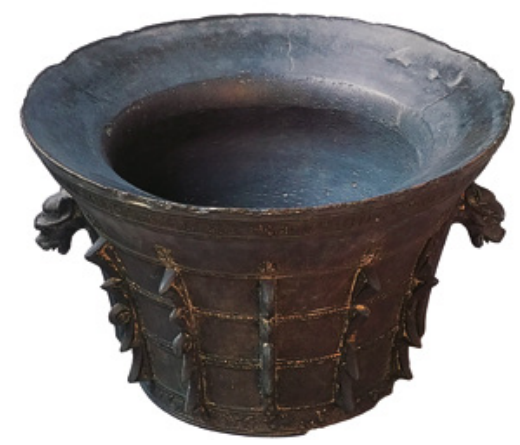
specifying more details.

Illustration 2. Bronze Mortar cast by Bernat Vidal in 1464 (Museu d’Història de la Ciutat de Barcelona, MHCB 251).

\footnotetext{
55. Camós Cabruja, Lluís. "Dietari de l'obra del rellotge i la campana del castell de Perpinyà l'any 1356", Homentage a Antoni Rubió...: III, 423-446.
} 
The inventory records another book worthy of mention: it is a manuscript signed by Palou himself and decorated with red and blue capital letters. In it he wrote down the accounts relating to the corambre and the debts of the banc dels hereus. The archive also specifies numerous testamentary documents and estates of the direct relatives of the Palou couple, as well as testamentary clauses of the wool carder, Pere Vidal, and of the bellfounder, Berenguer Vidal. These last manuscripts are among the sources relating to the Houses of Vila Nova, and next to a period of payment dated in 1408 and signed by Berenguer Vidal himself. The date refers to the years of activity of Pere and Joan Palou I. I do not know if there was any kinship or professional relationship between Palou and Berenguer Vidal - teacher / apprentice, for example-, but what I can be sure of is that Vidal did the same job as Joan Palou: it is confirmed by a document kept in the manual of the notary Joan Reniu, dated in the year 1423, where he appears cited as master bellfounder. ${ }^{56}$ Berenguer Vidal may have been part of another line of Barcelona foundry masters, whose most well-known member is Bernat Vidal. This craftsman was at the service of the Councillors of Barcelona and the kings Pedro de Portugal and Juan II, for whom he cast various pieces of artillery. In 1464, on the occasion of the appointment of Antoni Llonch as the fourth councillor of the city of Barcelona, he cast a magnificent mortar currently kept in the Museu d'Història de la Ciutat (illustration 2).$^{57}$ In 1472 , in thanks for the work done, Juan II granted him the rights to a mill in the Plaça de la Blanquería in Barcelona. ${ }^{58}$ Vidal exemplifies, more than any other craftsman, the close relationships between cannon makers and high dignitaries and institutional representatives.

The inventory of Joana Palou features a series of documents that tell us about the couple's properties in detail. Two of them are dated November $7^{\text {th }}, 1407$ and June $9^{\text {th }}, 1408$ and confirm the sale of a house. The house of Marcús must have been bought during the first third of the $15^{\text {th }}$ century. This is confirmed by the fact that, among the delivery notes of Joan Palou I's account book, there were those de la casa davant la capella de' $n$ Marchus ("of the house in front of the Marcús Chapel").

The evolution of the houses of Vila Nova or de les fusines can be followed with more precision. The documentary series begins on December $8^{\text {th }}, 1396$, when the bellfounder from Barcelona, Guillem de Puig, sold a house of Vila Nova to Bernat Bertran. The following year, Bertran sold it again to the bellfounder, Bernat Valor, and on December $8^{\text {th }}, 1406$, he resold it again to Joan Palou I. On March $17^{\text {th }}, 1417$ Palou acquired another property from Ginebra, wife of the Barcelona merchant Frederich Bou, who continued to live there until her death.

The archive registered in the inventory held several documents related to the casa de les fusines, which indicates an uninterrupted activity since the end of the $14^{\text {th }}$ century, although the clear reference to the workshop is only documented in

56. AHPB. Notari Joan Reniu. Manual (1423-1424), f. 17r.

57. Mora, Victoria. "Morter d'ús farmacèutic del conseller Llonch", La Barcelona gòtica. Barcelona: Institut de Cultura - Museu d'Història de la Ciutat, 1999: 238-239.

58. Vinyoles i Vidal, Teresa M. “Bernat Vidal, rellotger... ": 597-612. 
a letter dated November 1474. Finally, we know that Joan Palou acquired a third property from the merchant Esteve Doms between the years 1475 and 1476.

The inventory of Joana Palou's property allows provides an insight into the working, social and economic reality of a Barcelona cannon maker at the end of the $15^{\text {th }}$ century. In-depth analysis informs us of the daily life of this craftsman by identifying his property and real estate, domestic environment, work spaces and the tools used in his profession. The text also provides the opportunity to investigate other complementary aspects of a more social nature, such as the relationships established with his peers and with other artisan collectives.

Palou's professional biography is based on the sequence of documented works and tasks and the record of the activity carried out within the municipal council. It should be noted that the assignment of cannon makers to a strategic sector directly related to power structures, undoubtedly determined their privileged position within the menestralia (medieval artisan class).

\section{Annexes}

\subsection{Transcription of documents}

\subsubsection{Barcelona, 30 $0^{\text {th }}$ May 1495}

Chapters signed between the coppersmith, Joan Palou, and the jurats ("magistrates") and worker of the church and the parish of Sant Pere d'Octavià, located in the municipality of Sant Cugat del Vallès, for the construction of a new bell.

[AHPB. Notary public Lluis Carles Mir. Llibre comú (year 1495), f. 142v, 143r, 143v]

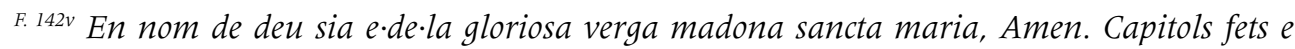
concordats per e entra lo senyer en Johan Palou, courer, ciutada de barchinona, de una part, e los senyors en Anthoni Canals, Pera Saguera, jurats, e Barthomeu Vilar, obrer de la sglesia e paroquia de sant Pera de Octovià, situats en lo terme de ${ }^{59}$ monestir de sant Cogat del Valles, de-la part altra, sobre les cosses deval scrites.

Primerament, lo dit Johan Palou fa venda als dits jurats e obrer de un seny o campana de tant per quant pessa un altre seny o campana trancada qui es en lo campanar de-la dita sglesia, abans de maior pes que de manor, lo qual se age de ffer dins la present ciutat de Barchinona, $e$ bo e rebedor, e lo qual promet donar e aportar a la dita sglesia e.pugar aquella al campanar ${ }^{F}$. ${ }^{143 r}$ de la dita sglesia, a.tot son cost mecions e-despeses, den per tot lo mes de juny primer vinent;

59. Followed by mon crossed out. 
e si dins lo dit temps no podia donar compliment a les cosses sobre dites, al-mes larch haie e sia tingut donar compliment a tot demunt dit de si mitgant mes de juliol primer vinent. Item los dits jurats e obrer prometen donar e liurar al dit Johan Palou la dita campana o seny trenquada qui viny (?) es en lo campanar de·la dita sglesia en aquesta fforma: ço es, que lo dit Johan Palou haia de venir a.la dita sglesia e trencar aquella en diversos trossos, de-manera que los dits jurats e obrer la puxen portar o fer portar a.coll de bestias en la present Ciutat de barchinona; e tranquada la dita campana o seny com dit es, los dits jurats e obrer haien e sien tinguts portar o fer portar aquella a.llur cost, mesions e despeses en la present ciutat de Barchinona, en casa del dit Johan Palou. E mes avant, ultra la.dita campana trenquada, los dits jurats e-obrer haien e sien tinguts donar e paguar al-dit Johan Palou, XVI lliures barchinonensis, les quals li haien e sien tinguts donar e paguar en continent que la dita campana o seny, la qual ara novament s.a de fer, sia feta, puiada e possada $<a l t>^{60}$ en lo dit campanar.

Item es concordat entra les dites parts que, encontiment que lo dit seny o campana lo qual es tranquat sia davallat, se haia a.pessar; e del pes que pessara de voluntat de les dites parts lo domer de $<$ la $>^{61}$ dita sglesia haia fer mensis en scrits; e si la campana o seny lo qual se ha de fer novament pesara mes que lo trenquat, los dits jurats e obrer haien e sien tinguts donar e paguar al dit Johan Palou, ultra les dites setze liures, dos sous $<$ barchinonensis ${ }^{62}$ per cascuna liura que lo dit seny nou pessara mes que lo trenquat; e si menys pesava, ${ }^{63}$ lo dit Johan Palou haia e sia tingut restituir e paguar als dits jurats e obrer a.raho de un sou moneda de barchinona per cascuna liura que menys pasaria del dit seny trenquat.

Item es concordat entra les dites parts que, si apres de esser acabat lo dit seny o campana e possat a aquel en lo campanar de la dita sglesia, sis mesos apres que bo sera possat per algu o alguns de la peroquia de la dita sglesia sera pretes que lo dit seny no sera bo e.rebedor, en-tal cars, volen e consenten les dites parts que sian elegits dos mestras de fer campanes, ço es un per cascuna part, los quals haien a.dir e-declarar lur parer, ab jurament si lo dit seny o campana sera bo e rebedor ho no; e si-per aquells sera declarat lo dit seny o campana no esser bo ne rebedor, en.tal cars los dits jurats o obrer no sian tinguts rebra lo dit seny o campana, ans lo dit Johan Palou sia tingut asson cost, e-mesions, e despeses tornar aquell en la forma demunt dita; effins sia judicat esser bo e rebedor com dit es, caro sia fet una vegada e moltes e. tantes com sia manaster. Item es concordat entra les dites parts que, en lo pugar del $<d i t>{ }^{64}$ seny $o$ campana al campanar de.la dita sglesia, los dits jurats e obrer haien e sien tinguts en-donar e ajudar al dit Johan Palou de.tants homens com seran necessaris en lo pugament del dit seny o campana, e totes altres coses que sien necessarias per lo puiament de aquell, exeptat empero corrioles, tales e libants, les quals lo dit Johan Palou pren a son carrech. E les dites cosses totes e sengles segons demunt son convengudes permetten les dites parts attendra, e.complir, tenir, e.servar, e contra aquelles no ffer o venir, per alguna causa o rao, sots pena de vint e sinch

60. In the upper line spacing.

61. In the upper line spacing.

62. In the upper line spacing.

63. Followed by e si mes pessava crossed out.

64. In the upper line spacing. 
liures barchinonensis guanyadora per lo tot a la part, ${ }^{65}$ obedient a les cosses demunt dites, complint e servant; e.perdedora ${ }^{F .143 v}$ per lo tot $<$ a la part ${ }^{66}$ contrafaent a les coses demunt dites, no complint ne servant la.qual pena sia tantes vegades comessa ${ }^{67}$ com en aço fos contrafet. E la.qual pena pagada o no graciosament retuesa, no.s.es menys les cosses en.los presents capitols contengudes, se hagen a.complir e-servar ab tot aspecte. E per ço attendre e.complir la una per a l-altra e endesemps se obligen tots lurs bens remuniran a.totes leys contrafayents e ho $<j u r e n>{ }^{68}$. E volen les dites parts que, dels presents capitols e.de·les coses en aquels contengudes, sien fetes a.les dites parts e a la stima de aquelles tantes cartes com demanades e requestes seran per lo notari dels presents capitols substancia no nindada.

\subsubsection{Barcelona, $27^{\text {th }}$ of March $-1^{\text {st }}$ of June 1526}

Inventory of the property of Joana, widow of the coppersmith, Joan Palou, carried

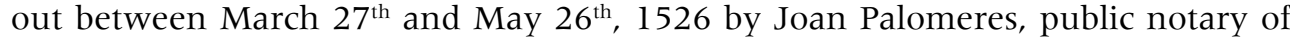
Barcelona by royal authority. Followed by the auction held in the Lonja de Mar between April $11^{\text {th }}$ and June $1^{\text {st }}, 1526$. Payment made to the notary Joan Palomeres for fees corresponding to the creation of the inventory and the sale, dated October $30^{\text {th }}, 1527$ is kept Between pages 25 and 26.

[AHCB. Notarial protocols: inventories. Inventari de Joana, vídua de Joan Palou, courer]

${ }^{F .1 r}$ [In the left margin]:

Inventarium hereditatis et Bonorum done Joanne quondam uxoris Joannis Palou quondam courerii

[In the right margin]:

Huic exord [...]

Inventarium [...] um de hereditate et bonorum done Johanne qui fuit uxore Joannis Palou quondam courerii, civis Barch[ino]ne die videlicet Lune XXVI mensis maii anno Nativitate Domini MD Vigesimo sexto per lo notarius civitatis.

Primo totes ayllens ab dos portals en la carrera publica obrans les quals la dita deffuncta habitava e stava per derrerrs dies en la present ciutat de Barch[ino]na, en lo carrer de·la capella de $n$ Marcus. E tes per certs Senyers acens.

65. Follows by aura deleted and faent crossed out.

66. In the upper line spacing.

67. Follows remessa crossed out.

68. Below, prometen crossed out. 
En la entrada de la dita casa:

Primo, una campana de coura gran o de norma de pes de III quintars o més.

F. Iv Item, una caxa de fusta d-alber ab pany e clau dins la quals se a trobaren los seguents:

Item, tres ploms de stany grans, los dos stenssats e l-altre bo y una pinta de stany y altrers trossos de stany, que tot pesa mig quintar y cinch ll[iu]r[e]s.

Item, III olletes de coure, pentes y foradades, y una cussavera (?) de aram ab la cuha o manech de ferro o d-acer y XXXII axetes coure, entre grans y petites. E mes LXXX mascles de axetes de coure, entre grans y petites. E dalt y més II poms e mig de canalobres de branques. $Y$ tot junt pesa mig quintar y vint ll[iu]r[e]s.

Item, una pica $<a b$ broch $>^{69}$ de pedra buydada per obs de premsar vi y ab son contra pes de una gran pedra.

Item, una armari gran de fusta de pi, molt vell y antich, ab pany e clau, dins lo qual eren les coses seguents:

Primo, $<$ V perells e mig $>^{70}$ de mollos ${ }^{71}$ de coure, entre grans e petits.

Item, una olla de coura trenchada. ${ }^{72}$

Item, mes dues axetes grosses de coure de aliub (?), dos falconets petits de coure a forma de stopetes de coure, e hun mascle de coure y IIII piquerols de coure. E mes III axetes grosses y hun mascle y altres menudaries de coure, que pesa tot dos quintars e mig.

F. ${ }^{2}$ Item, una olla vella de aram, dues bacines de aram, e una caldera de aram, e una altra caldareta petita e una bacina de lautó. Que tot pesa vint y dues ll[iu]r[e]s.

Item, una sort de ronyons de coura que pesen que pesen (sic) una rova y sinch ll[iu]r[e]s.

Item, IIII stallots grans de traginer, vells.

Item, una sort de ferro en moltes peces que tot plegat pesa hun quintar y dotze ll[iu]r[e]s.

Item, XVIIII peces entre martells, barrines $y$ dos strinyols y altres peces de pocha valua.

Item, III storns de foradar abtes per offici de courer y una barra vella y una axa guarnida ab son manech de fust.

Item, unes balanças grans de aram ab son calesto de ferro, guarnides e.bones.

Item, tres roves y deu ll[iu]r[e]s de plorm entre div[erses] ses peces.

Item, hun altre armari antich, ab pany e clau, dins lo qual eren les coses seguens:

Primo, hun sach petit de canyem dins lo qual havia XXV perells e mig de mollos de coure abtes per buydar pedres de artillaria, que pesa tot una rova y quatre ll[iu]r[e]s.

F. ${ }^{2}$ Item, III perells de fembas, dues axetes de coura d.una O minor que l-altre, III fulles de coure, dues trencadas y una sencera y altres pertios y hun cuvo de cup de coura, ${ }^{73}$ dos morterets de coura. Pesa tot mig quintar e quinze ll[iu]r[e]s.

Item, sis martells de ferro de div[er]ses sorts.

Item, sinch tenalles de ferro de di[ver]ses sorts.

Item, ${ }^{74}$ VIII limes entre grans y xiques.

69. In the upper line spacing.

70. In the upper line spacing, above dos perells struck through.

71. Followed by los quins struck through.

72. Followed by e una altra olla de aram trenchada.

73. Followed by pesen tot dues struck through.

74. Preceded by VIII li struck through. 
Item, una cassa de ferro per a.fondre plom, petita.

Item, un compas de ferro migenser.

Item, una anclusa de ferro petita.

Item, un axol de ferro ab son manech.

Item, unes tisores ab-les cames largues abtes per a-tallar ferro.

Item, una sort de trossos de ferro.

Item, vint pesos de pesar, de ferro, entre grans y xichs.

${ }^{F}{ }^{3 r}$ Item, unes manxes petites dolentes.

Item, una cassa de ferro ab un manech de fust.

En un altre calax del metex armari:

Primo, un liurador de fust en que ha polvora de pinguardes: II ll[iu]r[e]s.

Item, un altre armari en que ha una sort de $e^{75}$ ampolles de relotge per altres barbolleries.

Item, un paner y una sanalla.

Item, en la dita entrada, una roda de fust per afinar campanes de rotlle.

Item, dos plechs de fust que son molles de campanes.

Item, miga bota de dues carregues en-que-ha salpetre, que pesa IIII quintars, II arroves y miga, $y$ de refinada en un sac: XXIIII ll[iu]r[e]s.

Item, una romana petita en que entre lo pes major en miga rova.

Item, un taulell de fust ab un caxo.

Item, una carrega de lenya.

${ }^{\text {F. }}{ }^{\mathrm{V}}$ En lo pastador:

Item, un carratell de tenguda de mija carrega.

Item, una scopeta de coure ab-la guarnicio de fust de III palms y un quart.

Item, ${ }^{76}$ una pastera de pastar migencera y un cedas y scaleta de fust y se la de pastar migencera, usada.

Item, una bota de II carregues sense sol a.la hun cap.

Item, un cubell de fust gran ab son banch.

Item, un bugader gran engastat tot de terra.

Item, una caldereta de aygua beneyta de aram.

Item, una olla de aram ab dues anses.

Item, dos bacins vells d.aram petits trencats.

Item, $u n^{77}$ perol de aram desguarnit ${ }^{78}$ ab lo sol afegit que pesa XX ll[iu]r[e]s.

Item, una cassa de bugada foradada.

Item, una caldera de aram ab·sa ansa bona que pesa XVI ll[iu]r[e]s.

Item, una olla gran de coure sencera que pesa mig quintar y IIII ll[iu]r[e]s.

Item, dos batalls de campana grans que pesan dues arroves y XXII ll[iu]r[e]s.

75. Followed by vidre struck through

76. Followed by dos struck through.

77. Followed by a crossed out.

78. Followed by que pea pesa struck through. 
F.4r Item, una conqua de tinell de lauto ab sos bollons, peus y una ansa, que pesa XXX ll[iu] r[e]s.

Item, un caxo de fust en que.ha una sort de pesos de carnisser y altres coses, tot de coure, que pese XXX ll[iu]r[e]s.

Item, una sort de pesos de carnisser de plom y un patro de xeta grossa de ${ }^{79}$ plom y altres menarderies, tot de plom, que pesa tot una rova.

Item, una sanalla vella ab una sort de ferros vells que pesa XX ll[iu]r[e]s.

Item, ${ }^{80}$ dos banchs grans de quatre peges $d$-alber.

Item, una bancha de quatre peus.

Item, un coffret petit ferrat, sotil.

Item, un cauet dolent.

Item, un escambell de fust.

En lo sostret sobre lo pastador:

Primo, una gerra gran de terra farmera $i$ buyda.

Item, un tomis per passar arena.

Item, un bassi de lauto vell.

Item, una lanterna de correu guarnida de tela, dolenta.

F.4v Item, una mola de pedra de esmolar.

Item, dos banchs xichs de quatre peus y una banca de tres peus.

En un retret de la recambra dalt al primer sostre:

Item, un jaquet de dona de cadibaregues (?) forrat de pell blanca, usat.

Item, unes faldetes de dona de drap gris, usades.

Item, un devantal dolent.

Item, unes $<$ altres $>^{81}$ faldetes de dona ${ }^{82}$ usades de mescla scura.

Item, un tros de drap gris nou en·que -via mija cana.

Item, un cubertor de pastar de drap gris ${ }^{83}$ ja usat.

Item, un jaquet de Cadis negre ja usat.

Item, una taula plegadissa ab sos peges.

En la recambra al costat de la cambra major:

Item, XIII ${ }^{84}$ troços de drap de li per-a.servir, dolents.

Item, una tela de pastar ja usada.

Item, ${ }^{85}$ sis troços de draps per.a.servir.

Item, $<$ dues $>^{86}$ camisas de dona usades.

79. Followed by pell struck through.

80. Followed by uns struck through.

81. In the upper line spacing.

82. Followed by de struck through.

83. Followed by de pastar struck through.

84. Followed by to struck through.

85. Followed by si struck through.

86. In the upper line spacing, above the word una struck through. 
Item, un sayet vermell de dormir de nits molt usat.

${ }^{\text {F. }}{ }^{r}$ Item, una caxa de $e^{87}$ poll sens frontisses que trobam una sort de draps de cuyna.

Item, un sach de tres quarteres ja usat.

Item, un pom de panallo xiquet, de bressol, daurat.

Item, una post en que sta figurada la mare de Deu.

Item, un drap de pinsell molt sotil.

Item, un canalobre gran de lauto ${ }^{88}$ molt bell de sis branques.

Item, un banqual de fusta d-alber de una casa en que atrobam unes faldetes de dona, de drap de Cadis, molt usades.

Item, mes una gonella de dona, de Cadis, negre, molt usada.

Item, un sallo de home de drap negre, molt usat.

Item, tres panyos de.home de drap de li.

Item, dues coxineres de drap de li ja usades.

Item, un cos de ${ }^{89}$ brial de dona blanch de drap de li.

Item, una gonella de drap de mescla clar, mig usada, de dona.

F.5v Item, un scalfador de lit, d.aram, petit.

Item, una taula de verga de partera.

Item, un plat gran de terra.

Item, un cobri bancal barrat de quatre colors, mig usat.

Item, un altre bancal barra de colors, molt usat.

Item, una catiffa ab puntes ${ }^{90}$ de colors, molt usada.

Item, una altra catiffa de colors, de tres rodes, ja usada.

Item, una cadira de ${ }^{91}$ cuyro ja usada.

Item, un coxi de fluxell ja usat.

Item, un lit encaixat a.forma de colga ab un mathalas de $e^{92}$ pel.

Item, un caviller de fust com a.guardapols pintat de bermello, nou.

Item, una spasa de.la fulla ampla, antigua, ab pom y cruzeres.

Item, un drap de brots de Tornay, mig usat, qui stava al menjador.

Item, un saquet vermell de dormir de.nit, molt usat.

F. ${ }^{r}$ Item, un coxi de ploma ab sa sotana, ja usat.

Item, una canasta de verga gran ab una sort de papers.

Item, un retaule ab unes figures de n[ost]re s[eny]or ab papers.

Item, un coffre de·alber ${ }^{93}$ gran de.la forma major, ab pany y clau, en lo qual atrobam les coses seguents:

Primo, ${ }^{94}$ un perell de lansols de tres teles mig usats, de stopa.

87. Followed by alber struck through.

88. Followed by de VI struck through.

89. Followed by an illegible letter struck through.

90. Followed by molt struck through.

91. Followed by fust struck through.

92. Followed by borc $p l$ struck through.

93. Followed by $a b c$ crossed out.

94. Followed by tres crossed out. 
Item, mes dos perells de lansols de.tres teles de-stopa mig usats.

Item, tres lansols de quatre teles de stopa mig usats.

Item, una tela de davant.lo.lit de filempua ${ }^{95}$ encanyissada, grollera.

Item, tres coxineres de li primes, blanques, guornides de veta blanqua.

Item, una camisa de.home de lino usada.

Item, VI camises de·dona aldanes de·la deffuncta, de stopa.

Item, dues tovalles scacades oldanes de stopa.

Item, XI exugamans de cuyna ja usats.

${ }^{F}{ }^{6 v}$ Item, una sanalleta ab pedassos.

Item, un tros de drap de stopa nou que tira ${ }^{96}$ tres canes y miga.

Item, en un sach blanch, una sort de patrons de fusta $<$ per fer $>^{97}$ letres y unes cartes de patrons per fer dites letres.

Item, tem un caxonet en que.ha molts patrons de segells $y$ de dentells de morters $y^{98}$ dos jambinets y altres delicadures, tot de coure, que pesa tot encamarat una rova.

En la cambra major del primer sostro:

Primo, en lo mig coffre de la deffuncta, un rastre de saltiris de lambre.

Item, ${ }^{99}$ XXXVI perles migenceres.

Item, dues pedres $d$-anel sens encast.

Item, una tela $<$ de $>^{100}$ davant lit encanyassada, guarnida de flocadura blanca de filanpua.

Item, un lansol de IIII teles de bri, nou.

Item, tres canes y dos palms de filempua, nova.

Item, una cana y VII palms de drap de stopa nou.

F. ${ }^{\prime}$ Item, una cana y VII palms de drap de bri prim, nou.

Item, $<$ dues $>^{101}$ tovallolas y un capsó de orlanda prima, nou, per ligar dona.

Item, tres troços de filanpua, randat.

Item, una beatilla de coto que tira XV palms.

Item, un stox de cuyro ab un pes y.taules per scriure a.forma de libret.

Item, una pinta de pentinar molt lavorada.

Item, me atrobam ${ }^{102}$ dins lo dit mig coffre, entre ducats reals y menuts, VII liures.

Item, en un cabasset, una sort de papers de albarans y compres.

Item, unes ores de pergami de ma, cubertes de post.

Item, un tros de parge de vellut vert.

Item, sinch troços de lista blanca y negra obrada; tira XXX palms.

95. Very fine linen fabric, similar in transparency to gauze, woven from the thread that remains between the teeth of the carding comb the second time it is combed.

96. Followed by tres struck through.

97. In the upper line spacing.

98. Followed by altre struck through.

99. Followed by un struck through.

100. In the upper line spacing.

101. In the upper line spacing, above the word una struck through.

102. Followed by dit struck through. 
Item, un paner de palma y dues capses sense cubertor, de fust blanch.

Item, un vel de dona de dol.

Item, en una caixa grossa de navegar, XI torcaboques de stopa y coto

F.7v Item, XXXI torcaboques de bricoto prims.

Item, $V$ tovalloles de stopa bones.

Item, mes dues tovalloles de bricoto ab los caps desfilats primes.

Item, dues tovalles noves ab caps de stopa y coto.

Item, $V$ tovalles de stopa y coto usades.

Item, quatre perells de lansols de quatre teles migancers de bri.

Item, dos perells de lansols de tres teles, ja usats, de stopa.

Item, un coffre groch, gran, de alber, en que atrobam les coses seguents:

Primo, una loba de Cadis negre, nova.

Item, un mantell nou de Cadis, negre.

Item, un jaquet de saya, negre, folrat de tela negra.

Item, una gonella de Cadis negra, usada.

Item, un $\cos ^{103}$ de drap leonat ab·la manega streta, ja usat.

Item, un sayet de mescla scura ab la manega streta, usat.

Item, altre sayet de drap $<$ negre $>^{104}$ ja usat

F. $8 r$ Item, un altre sayet de Cadis negre, usat.

Item, xia de drap negre guarnit entorn de $e^{105}$ veta de seda negre.

Item, un gipó de fustani negre ab miges, maneguet y collar de vellut negre.

Item, altre gipo ${ }^{106}$ ab lo cos de fustani negre y les manegues y collar de vellut negre, molt usat.

Item, un cos de gipo de fustani negre, dolent.

Item, un lit gran encaixat, groch, d.alber, ab.sa marfega y tres mathalaffs de lana de Serdenya. Item, ${ }^{107}$ VII peces de cortinas pintades de pinzell, de praderia.

Item, una flassada vermella cardada, usada.

Item, en un armari en.la dita cambra en.que.ha dues ampolles que $\cdot y \cdot h a$ aygua naf ${ }^{108}$ y aygua $\operatorname{ros}^{109}$ y una flota de pedaços.

Item, una cadira de cuyro.

[]$^{110}$

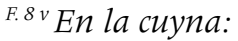

Primo, VII olles de coure en-que hi-a una trencada y quatre cassoletes de coure, tres xiques y una gran, que entre dites cassoles y olles pese tot mig quintar VI ll[iu]r[e]s.

Item, mes una altra semblant de la desus dita gran de coure, que pesa de quatre fins en sinch liures.

103. Followed by leonat struck through.

104. In the upper line spacing, above de do.

105. Followed by drap negre struck through.

106. Followed by de $f$ struck through.

107. Followed by una $q q$ crossed out and struck through.

108. Aigua nafa: "Orange blossom water".

109. Aigua rosa: "distilled rose petal water".

110. Crossed out: Item, VII olles de coure, les sis senceres e la una trencada. 
Item, un gambinet $y$ un perolet petits d-aram.

Item, un bassinet de lauto foradat per colar salsa.

Item, $X$ canalobres de lautó, VIII sencers $y$ dos tranchats.

Item, un pixer de lauto $a b<$ una $>^{111}$ ansa y broch.

Item, una copeta de lauto per a-taula.

Item, III asts de ferro xichs.

Item, una sort de piquerols y xetes ${ }^{12}$ y altres menuderies, tot de coure, que pese tot una rova $y$ vuyt ll[iu]r[e]s; fonch posat en.l-armari de·la entrada.

Item, un tinell de fust en.lo qual ha un canter de.aram gran ab-ses anses, sense cubertor.

Item, mes, tres cantes $d \cdot a r a m$ ab una ansa y broch, sens cubertor, ${ }^{113}$ los dos grans y l-altra petit.

F. ${ }^{r}$ Item, una torradora de castanyes de aram.

Item, un cossi de terra fes gran y un altre petit.

Item, dos menados de ast de ferro, de tres cames, la.hu gran l-altre petit.

Item, una paella de ferro ab sa giradora.

Item, una olla de aram gran ${ }^{114}$ de tenguda de dos cames o peus ab dues anses

Item, unes grailles de ferro que tenen VII barres.

Item, una copa d-aram mijgensera.

Item, un perolet d.aram ab una ansa mijgencera.

Item, un baci de lautó foradat, vell.

Item, hun forroll de ferro.

Item, un fogo de jueu de aram gran.

Item, dos morters de pedra.

Item, un moli de pedra per molre salses.

Item, ${ }^{115}$ XX escudelles de terra y XII plats.

Item, tres cubertores d-aram per cobrir olles, les dues grans y la huna petita.

Item, una salinera de fust de Ceuta.

Item, un morter de coure ab sa ma de coure, mygenser, per a.la·cuyna.

F.9v Item, ${ }^{116}$ sinch talladors de fust.

Item, sinc boxos y dos cullers de fust.

Item, una conca d.aram ab tres peus per ansabonar.

Item, un fogo de juheu migencer de 117 aram ab dos peus.

Item, un bancal de fusta molt sotil ${ }^{118}$ ab pany y sense clau.

Item, lo poal del pou d.aram ab una cassera y ab-sa corriola y corda y cadena

Item, VI ampolles $y$ dues castanyes.

Item, una conca de lauto ab tres peus, sens bollons, mygensera.

111. In the upper line spacing.

112. Followed by tot struck through.

113. Followed by la hu gran y struck through.

114. Followed by p [er] an struck through.

115. Followed by una struck through.

116. Followed by tres struck through.

117. Follows $f$ crossed out.

118. Followed by sens struck through. 
Item, una cadira.

Die Martis XXVII mensis marcii anno praedicto MDXXVI

En lo menjador:

Primo, una taula d-alber plegadissa ab IIII frontisses y ab dos capitells.

Item, una post de pastar.

Item, un scambell.

Item, una cadira de fust de costelles.

Item, un taulell per juga a.scachs ab un saquet ab los escachs y ab son joch de taules.

F. 10 r Item, Item, (sic), un coffre gran vell, de forma magor, de fusta d-alber, ab son pany y clau en que ${ }^{119}$ son les coses seguents:

Primo, unes tovalles de-la forma xica petites, scacades.

Item, unes altres tovalles semblants als prop dites.

Item, dues tovalles oldanes semblants a les prop dites.

Item, $<$ dues $>^{120}$ tovalles de ginesta grollera ja oldanes.

Item, sinch tovalles de.stopa bones, scacades.

Item, set embarrassadors de dona molt oldans.

Item, tres capells de dona redons ja usats.

Item, un boliquet de draps oldans de·li en-que.ha un davant altar ab perfil de filampua.

Sinch torquaboques, los quatre dolents y un bo.

Item, quatre culleres d-argent $<a b \cdot$ sa capseta $>^{121}$ que pesen III onses y un argens.

Item, una capsa redona vella, sens cubertor, ab un jesuset.

Item, un bancal de fusta d-alber usat, de tres cases, en que son les coses seguents:

Primo, ${ }^{122}$ un exugama usat.

Item, un sombrero dolent.

Item, una ${ }^{123}$ sort de molles de terra y de fust abtes per a.buydar.

${ }^{\text {F. } 10 \mathrm{v}}$ Item, un coffret xiquet de.fusta $d \cdot a l b e r$ ab son pany ${ }^{124} y$ clau.

$E n^{125}<$ una $>$ cambra del segon sostre qui trau fenestra al carrer major, en la qual cambra se.y entra per lo galliner; ${ }^{126}$ atrobam les coses seguents:

Primo, una caxa ferrada sens pany i clau en que ha un pot de vidre foradat ab tots los caps, abte per lanterna.

Item, una lantia gran y una ampolla per fer relotge.

Item, una caxa d-alber molt vella y dolenta sens frontisses.

119. Followed by ha struck through.

120. In the upper line spacing, above III struck through.

121. In the upper line spacing.

122. Followed by en la huna caxa struck through.

123. Followed by flor struck through.

124. Followed by e struck through.

125. Followed by la struck through.

126. Followed by Primo struck through. 
Item, un caxo pla en-que·ha una sort de barbolleria.

Item, una altra caxa d-alber ab pany y clau en.que atrobam les coses seguents:

Item, LXXXVIII rams de fil y XXI capdell de bri stopa, que entre tot pesa XVIII ll[iu]r[e]s.

Item, III ll[iu]r[e]s de lli en flota y migata.

Item, una gerreta verda ab quatre anses y una scudela grasalada.

Item, una sort de posts velles en-la·dita cambra.

En lo galliner:

Primo, un banch de quatre petges.

F. 11 r Item, III gallines, II negres y una rossa.

Item, un armari molt dolent.

En una altra recambra al costat del galliner:

Primo, una gerra gran en que ha poch mes o menys un quintar d-arena blanca de·les judies, abte per fer relotges.

Item, una canal de terra.

Item, un ast de ferro ab son menador.

En una altra cambra al segon sostre ${ }^{127}$ pujant per la scala a.ma.squerra:

Primo, una caxa ferrada ab son pany y clau dins la qual atrobam les coses seguents:

Item, una vanova de·la.forma gran, de drap de compra sembrada de unes regoletes $y^{128}$ de animals.

Item, mes dos coxins de parar, de la forma major, goarnits de cordo vert de seda.

Item, un perol gran d.aram ab dues anses.

Item, un cobri bancal barrat molt sotil.

Item, un drap de pinsell.

Item, una roma $<$ molt ${ }^{129}$ gran de ferro ab son pilo que s.i pot pesar en lo pes major de VIIII quintars fins en $X$.

F. 11 v Item, un tros de marfegota molt vella.

Item, una talla de fust ab sa corda molt usada.

Item, dos covens de verga.

Item, un quintar de carbo.

En la cambra maior del segon sostre, pujant per la scala a.ma.dreta:

Primo, un bancal molt gran de fusta d:alber de tres cases en que trobam les coses seguents: Item, XVII torcaboques grans, ço es, XIII de bri a-soles y IIII tramats de cotho.

Item, IIII coxineres grans, ço es, III de cotonina y una de bri, ${ }^{130}$ les tres goarnides de veta y la una de flochs y botons.

127. Followed by qui struck through.

128. Followed by $p[e] l s$ struck through.

129. In the upper line spacing.

130. Followed by guar struck through. 
Item, III tovalloles de stopa, bones, ab caps.

Item, dues tovalles de stopa scacades, mig usades, grans.

Item, dues tovalles de coto scacades, noves, grans.

Item, unes tovalles de genesta grans.

Item, ${ }^{131}$ tres lansols de dues teles ja usats.

Item, dos lansols de tres teles bons.

Item, un lansols de tres teles y miga molt usats.

Item, un lansol de tres teles vell, dolent.

Item, en l-altre calax del dit bancal, dues todoneres de terra.

Item, unes pintas de pentinar lin y una sort de papers de.squinsar.

${ }_{\text {F. } 12 r}$ Item, en ll-altre casa del-dit bancal, un filat que.s diu batuda de pescar.

Item, una altra sort de papers vells.

Item, mes tres draps de cuyna.

Item, un guarda pols de fusta pintat de vermell.

Item, III ${ }^{132}$ coxins de ploma per a dormir ab ses sotanes.

Item, en un coffre de·la forma major en-que trobam les coses següents /de fusta d-alber, sens pany y clau:

Primo, un brial de cotonina blanca, sense manegues, ab cos.

Item, dos coxins de parar plens de palla ab les sotanes de stopa, ab ses coxineres obrades de vert y grana a la morisca.

Item, tres catiffes de tres rodes de colors, bones.

Item, un exalo ${ }^{133}$ vermell de.la forma major, pintat de negre, molt bo.

Item, un cobri bancal de colors ja usat.

Item, un retaule <gran $>^{134}$ de la mare de Deu, ab son fill al bras, $b$ altres figures y titols.

Item, un altre guarda pols de fusta d-alber, vell.

Item, un altre coffre de fusta d-alber, de forma major, en que atrobam circa de tres aroves de farina poc mes o manco.

Item, una cadireta de costelles petita.

F. $12 v$ Item, un altre coffre de la forma major, d-alber, ab son pany y clau, en.que trobam les coses seguents:

Primo, sinch lansols de tres teles, de stopa, ja usats.

Item, dos lansols de quatre teles molt usats, de stopa.

Item, VIII tovalles de bri y estopa, molt usades.

Item, XVIII torcaboques molt sotils y squinsats.

Item, una sort de coure ${ }^{135}$ que pesa V arroves y VIII ll[iure]s, ço es, gambins xichs, xetes, perols, campanes, molles $y$ altres coses ${ }^{136}$ de coure.

131. Followed by un perell struck through.

132. Followed by $e$ struck through.

133. Quilt made with a type of cloth called xaló.

134. In the upper line spacing.

135. Followed by $V$ struck through.

136. Followed by es struck through. 
Item, un bancat de fusta d-alber; te dues cases, buyt / de fusta d-alber.

Item, un lit gran de la forma major, ço es, banchs y post y una marfega gran plena de palla, dos matalassos de lana de Serdenya ab.les cubertes de.cotonina y les sotanes de canyem, ab un parell de lansols de tres teles ja usats y sotils.

Item, una flassada cardada usada.

Item, un cubertor de.lit de diverses colors, barrat, ab uns senyals de.barres de arago.

Item, sis peces de cortines de tela negra, molt usades, ab barres blanques de III en III. ${ }^{137}$

Item, una pollera.

Item, un scambell.

Item, avall lo lit de dita cambra atrobam una sort de papers ${ }^{138}$ F. 13 r $y$ de cartes de pergami.

Item, un barral de tres quartes y mig de vidre cubert ab un sarrio vuyt.

Item, una olla de terra ab un cubertor y nanses abte per a recoure vidre daurat.

Item, una sistella de verga gran, dolenta.

En una cambra del tercer sostre, pujant per la scala a.ma squera:

Primo, una caxa ferada xica, dolenta, ab pany y clau, en.que.ha LXI cresols $<$ de terra $>^{139}$ petats $^{140}$ abtes per a.fondre metall.

Item, un cove de verga molt dolent en.que.ha una sort de cresols de terra semblants als demuntdits.

Item, una caxa gran, grossa, de·navegar, d·alber, en·que trobam dos cabasso que y ha una rova de polvora de.spingarda poc mes o manco.

En un porche de.la dita casa:

Item, tres mollos nous de buydar trompins, de fusta, ab ses post y guarniment.

Item, quatre mollos de fust, vells, per buydar trompins, ab ses post y guarniment.

item, un fornell de ferro <gran>, ${ }^{141}$ guarnit d.argila, ab sa corriola, abte per fondre metalls, ab sa talla.

Item, una asta de lansa sens ferro, grossa.

${ }^{\text {F. } 13 v}$ Item, una pastera de fusta vella ab sos peus, vella sotil, sens cubertor.

Item, un fornell <petit $>^{142}$ de ferro, guarnit de argila, ab sa talla, abte per fondre metall.

$[143]$

Item, unes manches migenceres ab dos canyons de ferro, abtes per manxar als fornals de fonre metalls, sotils, y un banquet de IIII peus petit.

Item, un armari de fust ab ses portes, vel.

Item, una sort de patrons de fust $<y$ de terra $>^{144}$ abtes per fer molles per buydar.

Item, un taulellet de fusta molt dolent.

137. Followed by I struck through.

138. Repeats de papers.

139. In the upper line spacing.

140. Followed by per a $\mathrm{f}$ struck through.

141. In the upper line spacing.

142. In the upper line spacing, above xiquet struck through.

143. In this line there is the following phrase, crossed out Item, unes $<m a>$ de dos canons petites.

144. In the upper line spacing. 
Item, sis mollos de ferro vell, migencers, abtes per buydar metall, fets a quatre cayres.

Item, sinch tenalles de ferro vell, grans, abtes per traure los cresols del fornell.

Item, sinch vergues de ferro, de largaria de V palms, abtes per atiar al foc per-al offici de courer. Item, dues barrines grosses abtes per-al offici de courer.

Item, XIIII ganxos de ferro vell, de largaria d.un palm, abtes per als mollos de buydar. Item, una sort de ferro vell, poca quantitat.

En un altre porche de la dita casa al costat del prop dit porcho atrobam les coses seguents:

F. 14 r Primo, una flassada cardada blanca, nova, ab listes a cada cap de tres colors.

Item, una.altra flassada cardada blanca sotil.

Item, una gerra gran de terra.

Item, una barrina molt gran abte per lo offici de courer.

Item, dues limes de ferro, la huna ab manech y l-altra sens manech.

Item, una cervellera de ferro molt vella, antigua.

Item, un banch de quatre peus ab una post travessera entre.les cames.

Item, una pastera gran de fusta sens cubertor ab son peu, vella.

Item, una taula petita ab sos petges, plegadissa, vella.

Item, una capseta de fust plena de batalleres de ferro.

Item, una taula gran plegadissa, sense petges, vella.

Item, una cadira de costelles vella, dolenta.

Item, una gran sort de mollos de fust $y$ de terra ${ }^{145}$ abtes per buydar artelleria e altres coses.

Item, tres limes ${ }^{146}$ de ferro migenceres.

Item, una anclusa de ferro migencera.

Item, un banch $<$ de fust $>^{147}$ ab ses peges, ab son caragol de ferro y la nou de coure, abte per limar les coses buydades de coure.

F. $14 v$ Item, sinch $<$ cly de $>^{148}$ ferros de tornejar, abtes per tornejar.

Item, dos banchs de quatre peus ab dues post grosses de.sobre.

Item, dues llates velles

En lo repla al costat de.la scala:

Item, dues gerres migenceres en $q u e \cdot h a$ olives.

Item, unes debanadores ab peu de canya.

Item, mes trobam una sort de plom en-que.ha molts patrons de campanes y.de figures y moltes altres coses y barbolleries, que pese tot V arroves y VI ll[iu]r[e]s, lo qual plom an posat en un bancal del menjador.

Item, una altra sort de plom, ço es, patrons y altres menuderies, que tot pese VI ll[iu]r[e]s.

145. Followed by Ite crossed out and struck through.

146. Followed by $y$ una struck through.

147. In the upper line spacing.

148. In the upper line spacing. 
Item, mes ${ }^{149}$ atrobam en la dita casa un libre de compte que comense la primera pagina 'fonch comensat lo primer libra a $X$ de gener del any $M D V^{\prime}$, etc, que ha XXXXVI fulles $y^{150}$ lo darrer partit acabe a IIII de abril de MDXVI 'doni al Senyer en Pere Vilar per matalls, pesaven I l[iur]a X onses'.

En l-altra pagina ha hu partit que diu 'Deu lo Senyer en Deia [la]toner' \# mes hi ha V querns tots blanchs de forma de full en.dit libre.

F. 15 r Item, a la fi de dit libre ha tres pagines e miga scrites, lo principi de les quals comensa 'sia recort a.mi <Gregori> ${ }^{151}$ Johan Palou, courer, que a $V$ de maig de MDXIIII me fou feta diffinicio de tots drets' \# E acaben les dites tres pagines y miga 'Sia recort a.my, Johan Palou, com havem ensetada la gerra del oli' \#; en.les cubertes ha un quern de XIIII fulles y $V$ altres trossos de papers.

Item, un altre libre de comptes de.la matexa forma en lo qual ha CXXXVIIII fulles scrites totes. Comense la primera 'Ihs Maria. En nom de Deu sia e de madona Sancta M[ari]a que m.endres en.tot be, amen; fou divenres a XXIII de juny del any LXXX' \#; acaba la ultima linea 'no tinch a pagar perque sino ço que $n$ he pagat com lo compri' \#.

Item, un altre libre <de comptes $>^{152}$ de la metexa forma en-que.ha LVII fulles y un partit scrit de.la ma del dit Palou y comense la primera pagina antichs y 'abat de Sent Lorens' \# y.en la segona pagina de.la metexa fulla <diu> ${ }^{153}$ 'comensat en lo mes de setembre de LXXXXVII'; apres diu ${ }^{154}$ lo primer partit 'Deu $i$ fou a X de LXXXXVI ${ }^{\text {F.15v }}$ de LXXXXVI com mosse Joffre de Seanmenat' $y$ acaba apres la fulla LXII 'Deu mossen Cortes que a X de octubre' \# en lo qual ha serca de VIII querns en blanch y a la fi ha VI fulles y miga scrites y comense lo primer partit 'Deu.me a.mi, Johan Palou, la taula de.la ciutat per ço que' \#; acaba lo derrer partit de la ultima fulla del dit libre 'Deu que he donades sis liures' \#.

Die mercurii XXVIII mensis marcii anno praedicto MDXXVI

Item, un altre libre <de comptes $>^{155}$ de ${ }^{156}$ la matexa forma en lo qual ha VIII querns, qui occupa CLXXXXIIII cartes y ani tres de squinsades que no.s.tenen en lo libre. Lo qual libre comense lo primer partit 'fonch comensat lo primer libre en maig de MCCCCLXXXVII'. E comensa lo derrer partir de dit libra 'Dech an en Bernat que divendres a VIII d'agost' \#. Item, un altre libre <de comptes $>^{157}$ de la metexa forma, nou, ab la rubrica qui.s te en lo dit libre de capletres bermelles y blaves, lo qual es de.n Johan Palou, en lo qual libre ha scrites VII cartes en-les quals VII cartes ha scrits LXVII partits, lo primer dels quals comensa' an apar tot lo compte del cuyram' \# ${ }^{\text {F.16r }}$ y lo derrer partit de dit libre comensa 'mes es degut al ${ }^{158}$ banch $^{159}$ dels hereus' \#.

149. Followed by $a b$ struck through.

150. Followed by per struck through.

151. In the upper line spacing.

152. In the upper line spacing.

153. In the upper line spacing.

154. Followed by Den struck through.

155. In the upper line spacing.

156. Followed by forma de struck through.

157. In the upper line spacing.

158. Followed by the $s$ of the plural form, crossed out.

159. Followed by the $s$ of the plural form, crossed out. 
Item, mes un altre libre de·la metexa forma, de compte, tot escrit, en lo qual ha V querns que occupen CXXXXII fulles. Lo primer partit del dit libre comense 'fou a VI de mars XLVIIII' \# y lo derrer partit de dit libre comense 'Deu lo senyer, en Sola, any Johan Palou' \#.

Item, un altre libre de la metexa forma, de compte, lo qual te quatre querns que occupen $C$ fulles. Lo primer partit del dit libre comense'Jhs, en nom de don, sia divendres a XII del mes d.abril del any CCCCXXXXIII' y lo derrer partit de dit libre comense 'es recort any Johan Palou' \#; en lo qual libre ha XV cartes totes blanques sens scrit algu.

Item, Item, (sic) un altre libre de comptes $<$ de forma $>^{160}$ en.quart de full, ${ }^{161}$ tot scrit, lo qual occupa CXXXXII fulles.

Item, un altre libre de dita forma, de comptes, part scrit $y$ part blanch, qui comense lo primer partit de noembre a XXVI dies.

$\left[{ }^{162}\right]$

Item, un libret de compte, de.full ${ }^{163}$ part escrity part blanch, en lo qual ha scrit alguns albarans de la casa davant la capella de·n Marchus e-alguns comptes de·n Johan Palou, lo qual libre ocupa LXXXXI fulles y comense lo primer partit de dit libre F.16v'Item, me deu lo senyer en Dalmau Palou, courer' \#.

$\left[{ }^{164}\right]$

Item, una carta en sa pubblica forma de deffinicio, la qual feu madona Margarida, muller de.n Miquel Cassa, qui.s carnisser, ciutada de Gerona a ${ }^{165}$ Johan Palou, germa seu, de tots los drets e actions que.li pervenguessen e los bens de aquell feta en Barchino a XXVIII de gener de MDII, en poder de.n Jaume Mas qui es notari de Barch[ino]na, e closa per ${ }^{166} n \cdot$ Anthoni Angles, notari de Barch[ino]na.

Item, la carta en sa publica forma de.les cases de la dita deffuncta, ço es, la segone seriga que feu Johan Torres, sastre, a.March Julia, matrasser, en poder de·n Pere Ortis, notari de Barch[ino], a VIIII de juny (?) de MCCCCVIII, es hi la possessio de dita casa y apoca del p[agamen]t (?). Item, altra carta vella en.sa.publica forma ${ }^{167}$ de ${ }^{168}$ la venda de la dita casa feta per en Jaume Berenguer, mestre de cases, a Johan Torra, sastre, a VII de noembre de MCCCCVII, closa per lo dit Pere Ortis, notari.

F. 17 r Item, una altra carta en forma d-aquelles cases situades en-la dita Ciutat, en lo loch dit la Vila Nova, de venda feta per madona Genebra, muller de·n Frederich Bou qui.s mercader de Barch[ino]na a Johan Palou, courer de dita ciutat, a XVII de març de MCCCCXVII, closas per.en Raphel de Brugia, notari real.

160. In the upper line spacing.

161. Followed by lo struck through

162. There is a crossed out sentence in this line: Item, un libret en lo qual ha alguns albarans e comptes de.n Joan Palou de la casa de la boria capella de.n Marqus.

163. Followed by en struck through.

164. There is a crossed out sentence in this line: Item, un libret def devvyute de full de compte.

165. Followed by Berthomeu Palou struck through.

166. It repeats $p[e r]$.

167. Followed by de la venta struck through.

168. Followed by dites cases struck through. 
Item, altra carta en forma de venda de les dites cases feta per en Bernat Bertran a $n$ Bernat Valor, mestre de ${ }^{169}$ campanes a XVII de juny de MCCCCLXXXXVII, closa per Pere de Brugia, notari publich de Barchino.

Item, altra carta en.forma de venda de·les damunt dites cases, feta per Guillem de Puig, mestre de campanes, ciutada de Barch[ino]na, abent valor a VIII de decembre MCCCLXXXXVI, en poder de dit notari.

Item, altra carta de venda, en sa publica forma, de les damunt dites cases feta per en Bernat Valor, mestre de campanes, a.n Johan Palou a VIII de desembre de MCCCCVI, closa per dit notari.

Item, altra carta de venda de dites cases feta per dit Bernat Valor al-dit Johan Palou a VIII de desembre de CCCCVI, closa per dit notari.

Item, altra carta de venda en forma ${ }^{170}$ dites cases feta per March Camps, causidich, ciutada de Barch[ino]na, a Johan Palou, courer de la dita ciutat, a VIII del mes de noembre de MCCCCLXXV, closa per lo discret Pere de Vesa, ${ }^{171}$ notari $p$ [ublic] de Barchinona.

${ }^{F .17 v}$ Item, una altra carta de una scrip[tur]a dada sobre dita·casa com:a.bens judefesos que foren de Joana Forn, dada en la cort del Veguer, a IIII del-mes de juliol de MCCCCLXXV, closa per Miquel Senya, notari regent la scrivania del veguer de dita ciutat.

Item, altra carta de requesta feta per Anthoni Fas, clergue procurador per lo venerable mosse Marti Johan de Foxa, canonge de Barchinona, y March Camps, causidich, en certs noms a Gabriel Soler, afinador de mesures, a III de gener de MCCCCLXXVI, closa per dit Devesa.

Item, altra carta ${ }^{172}$ procuria feta per Marti Johan de Foxa, canonge de la seu de Barch[ino] na, en cert nom a.n March Camps, causidich, en cert nom de les demunt dites cases, closa per dit Devesa, notari de Barchinona.

Item, altra carta petita de procura feta per Steve Domps, mercader ciutada de dita ciutat, en cert nom a.March Camps, causidich, a XIII de juny de MCCCCLXXV, closa per Hieronym Çafont, notari com a-tenint y possehint les scriptures de Matheu Çafont, pare seu.

Item, una carta de la possessió de dites cases dada per Esteve Doms, mercader, en cert nom a Johan Palou, courer de la dita ciutat, a XVII de abril de MCCCCLXXVI, closa per dit Pera de Vesa.

F. 18 r Item, altra carta de cura dada per lo veguer de Barch[ino]na als bens del dit Jaume Forn al dit Pere Doms a XXVII de gener de MCCCCLXXV closa per Miquel Carbo, notari publich de Barch[ino]na.

Item, un tre[s]lat autentich de una clausula de herencia ${ }^{173}$ treta del testament de $\cdot n$ Pere Vidal, perayre, clos per Francesch Borrell, notari p[ublich] de Barch[ino]na, tenint les scriptures de·n Bernat de Brugia, notari p[ublich] de Barch[ino]na.

Item, altre treslat autentich de la clausula de·la herencia del testament de Brenguer Vidal, closa per Berthomeu Agelli, notari public de Barch[ino]na.

169. Followed by simbols struck through.

170. Followed by de struck through.

171. Refers to the notary public, Pere Devesa.

172. Followed by de stablimie strcuk through.

173. Followed by feta struck through. 
Item, unes cartes velles de les dites cases, a la una sots kalendari a XVII de mars y MCCCLII, closa per Francesch de Lato, notari p[ublic] de Barch[ino]na; l-altre sots kalendari ${ }^{174}$ a XXVIIII de mars MCCCCVIII, closa per en Bernat Alamany, notari p[ublic] de Barchino.

Item, altra carta petita de.la apoca del preu de les dites cases feta per mosse Pere Ragassol, canonge de Barchinona y Guillem de Puig a Bringuer Vidal MCCCCVIII, closa per Bernat Alamany.

Item, $<$ una $>{ }^{175}$ carta $<$ procuria $>176$ de les damunt dites cases feta per los canonges del monastir de Santa Aularia del Camp de Barch[ino]na a.madona ${ }^{F}{ }^{18 v}$ Ginebra, muller de.n Federich Bou, ciutada de Barch[ino]na, a III de abril MCCCCXIII, closa per Bernat Berthomeu Ribes, notari public de Barch[ino]na.

Item, una apoca feta per dita Ginebra a.Johan Palou, courer, del preu de les dites cases sots calendari a XII de juny de MCCCCXVII, closa per en Bernat de Brugia, notari p[ublic] de Barchi[no]na.

Item, tres cartes velles del obrador de.les cases hon mori la dita deffuncta, la una sots calendari de XXII de noembre de MCCCCLXXIIII e closa per Anthoni de Çaplana, notari.real, e l-altra $<d e>^{177}$ stabliment de dit obrador, sots calendari de XXII de noembre de dit any, closa per dit notari.

L.altra sots calendari de VII del mes de noembre de dit any, closa per Pere Ortis, notari de Barch[ino]na.

Item, una altra carta de la venda de las predites cases feta per Vicens Çaplana a.n Georgi Guarriga, closa per Pere de Fogues, notari public de Barchino, sots calendari IIII de gener de MCCCCXVIII.

Item, un testament de la dona Margarida, muller de Johan Palou, fet a XXXI de març MCCCCXXXI, clos per Bernat de Brugia, notari p[ublic] de Barch[ino]na.

${ }^{\text {F. } 19}$ Item, altre testament de madona Margarida, muller de Pere Palou, fet a XXVI de març de dit any, clos per dit notari.

Item, un libret de albarans dels censos que.s.han pagat de les dites cases e altres coses.

Item, un altre libret de albarans dels censos ques son pagats de la casa, lo derrer del qual es de XXVII sous per la paga de Nadal de MDXXVI.

Item, un libret de albarans intitulat 'Libre dels cens de la fusina'. Lo derrer albara continuat en dit libret, fet per Jaume Sitgar, canonge de Sent-ana, de quantitat de nou sous per los cens de les fusines ${ }^{178}$ e.per la paga que caygue a-sent Johan de juny de MDXXV fet a XV d-agost de dit any.

Item, altre libret de albarans ${ }^{179}$ dels censos ${ }^{180}$ de la casa de la Vilanova; en lo albara darrer scrit en dit libre de ma de mosse Anthoni Marti, prevere, de XVIII en que fa la dita casa de cens, los quals confessa aver rebuts per la paga de sent Johan de MDXXV.

174. Followed by de struck through.

175. In the upper line spacing, above altra struck through.

176. In the upper line spacing, above de la venda struck through.

177. In the upper line spacing.

178. Followed by fet struck through.

179. Followed by en lo q struck through.

180. Followed by de les fusines o struck through. 
Item $^{181}$ unes cartes molt velles e altres scriptures que no importen res.

F. 20 r Supraedicta ${ }^{182}$ die martis XXVII mensis marcii anno praedicto a $I$ di XXVI Item, unes cases prop la plaça de·la Vila nova anomenades les fusines.

En la entrada de -las ditas casas:

Primo un barril petit prop de ple de terra de scombraries de coure.

Item, una gran quantitat de molles de terra abtes per fer olles de coure.

Item, unes manxes grans de forma major rahonables ab-sos canons de ferro ab-sos setials.

Item, una sort de molles de terra abtes per buydar campanes.

Item, una post gran d-alber.

Item, un morter de pedra molt gran y bell.

Item, un cavet ab son manech.

Item, unes manxes mygencere de fornal de argenter, velles, sotils.

Item, un molle de fust ${ }^{183}$ de XXX palms o mes, abte per fer alguna colobrina.

Item, una talla de.fust ab una corriola.

${ }^{\text {F. } 20 v}$ En una botiga al costat de la entrada:

Primo un carratell en $q u$ ue ha VI arroves y miga de sofre de roca.

Item $^{184}$ dos carratells y una bota sense sols.

Item, un taulell y una caxota sense cubertor.

Item, una carrega de llenya de pi.

Item, una sort de bigues y post.

Item, sis peces de quintars y mig quintar abtes per pesar.

En l-altra botiga gran:

Primo, una taula molt dolenta ab frontisses ${ }^{185}$ ab sos petges.

Item, un banch de quatre peus migencer.

Item, un pilo de fust ab tres peus ab un pico.

Item, una sort de posts y barres velles.

Item, un morter gran de pedra per picar polvora.

Item, tres moles de pedra, les dues de VI palms, la una de IIII.

Item, un moli abte per molre polvora.

Item, $V$ cubells, los tres buyts. Dels dos en la·que ha soffre picat cerca de tres arroves, poc.mes o menys, y en l-altre carbo molt.

F.21r Item, un morter de pedra gran.

181. Preceded by Item struck through.

182. There is a $g$ crossed out among vowels.

183. Followed by $a b$ struck through.

184. Followed by $V$ struck through.

185. Followed by Item, un banch ab $g$ struck through. 
En un sostro de·la d[it] a casas:

Item, una gran sort de carbo que hi.a VIII o X quintars, poc mes o menys.

En lo porcho sobre la entrada:

Item, una gran sort de molles de terra abtes per fer olles de coure y campanetes y altres barbolleries.

Item, tres post de vergar stany, una gran y dues petites.

En un menjador sobre la botiga xica:

Primo una taula dolenta $a b$ dos petges ab frontisses.

Item, una caxa ferrada vella sens pany y clau, buyda.

Item, un sach blanch dolent en que $\cdot h a^{186}$ sofre ${ }^{187}$ vert de cano que.pesa tres arroves $y X X$ liures. Item, XXVIII scobes de palma xiques.

Item, una altra caxa de fust ab pany en que.ha mig balo de tatxes menudes y alvirament de una liura de polvora de spingardes.

F. 21 v Item, dues gaffes, una de.ferro, l'altra de fust, abtes per a.fer colar botes.

Item, un canalobre de ferro gran ab ${ }^{188}$ VIIII stancies per tenir les candeles.

Item, una massa de ferro gran ab son manech.

Item, una altra massa de ferro migana.

Item, dos magalls de ferro.

Item, dues picases de ferro.

Item, dues tanalles de ferro grans.

Item, una destral dolenta ab son manech.

Item, unes mordaces de ferro largues abtes per traure cresols del fornal.

Item, ${ }^{189}$ una ancluseta petita.

Item, una romana gran ab.son pilo de plom que entra lo pes majo en $V$ aroves y lo menor en una rova.

Item, una serra gran de una ma.

Item, quatre barres de ferro grans abtes per atiar als fornals.

Item, una gran sort de ferros vells que pesen un quintar y mig.

Item, dues talles de coure ab quatre poliges ab sa corda de canyem.

${ }^{\text {F. } 22 r}$ En la cambra prop lo dit menjador:

Primo una caxa gran, Valenciana, ab son pany y sobre pany, sens clau, buyda.

Item, una altra caxa dolenta de navegar, gran, en que ha una poca de polvora dolenta.

Item, un coffre gran a.la Valenciana fet $<$ servia $>^{190}$ per tenir polvora, antich, buyt, pintat, sens pany y clau.

186. Followed by $f$ struck through.

187. Followed by de struck through.

188. Followed by nou struck through.

189. Followed by I struck through.

190. In the upper line spacing. 
Item, un altre coffre ab pany y sobrepany, $d \cdot a l b e r$, pintat de groch, en·que ha tres arroves de polvora ${ }^{191}$ y miga de bombardes.

Item, un quintar $y X$ liures de ronyes de coure.

Item, mes una corda de canyem larga, grossa, bona.

$\left[{ }^{192}\right]$

Item, dues conques, un baci, e un caldero tot trencat, de aram, tot trencat, que.pese tot XXVIII liures.

Item, mes un poal d.aram ab asa y anell de ferro, foradat.

Item ${ }^{193}$ atrobam una casa que afronte ab la cantonada de $\cdot$ la vila ${ }^{194}$ nova y es davant la casa de mossen $<$ Reig $>{ }^{195}$, notari de Barch[ino]na.

F.22v Item, una sort de ferro vell [...] Rova.

Dei enim bona et plura

[Following is the public aution held in the Lonja de Mar between April $11^{\text {th }}$ and June $\left.1^{\text {st }}, 1526\right]$.

\subsection{Documented buyers of Joana Palou's possessions at public auction}

Farmers-cattle breeders:

Anthoni Coll, pagès

Genís, pagès

Ribelles, paller

Apothecaries:

Johan Solsona, apotecari

Hieronimus Boter, apotecari

Metal artisans:

Joan Gracia, argenter

Anthoni Sanora, bombarder

Bernat Verom, ferroveller

Joan Joan, ferroveller

Franci, ferrer

Grau Mir, ferrer

Grau Lorens, ferreter que estava davant de la Llotge

Rocha, ferrer

191. Followed by de $b$ struck through.

192. Crossed out Item, una biga.

193. Followed by una casa struck through.

194. Followed by $b$ struck through.

195. In the upper line spacing, above rig lo struck through. 
Textile artisans:

Bernat Soler, sastre

Francesch Grotea, sastre

Johan Vidal, perayre

Sirachs, teixidor de lana

Artists:

Joan Asamort, pintor

Carpenters:

Johan Ferrer, fuster

Gabriel, fuster

Sales intermediaries:

Civera (o Sivera), corredor de la present ciutat

Franci de Lima, corredor

Querol, corredor de la present ciutat

Ecclesiastics:

Anthoni, frare del Carme

Jaume Calbis, prevere

Mossen Jaume Armengol, prevere vicari del Pi

Pere Bassa, prevere

Mossen Joan Solsona

Mossen Pons del Carme

Mossen Saliteda

Squires and servants:

Miquel Ferra, ascuder

La dida Tomasa Garcia

Foreigners:

Johan, lo Aragonès

Senyora valenciana

Un mallorquí

Not specified:

Johan, lo Vergueta

Sailors:

Rodrigo, mariner

Public notaries:

Jaume Mateu, notari

Jaume Mateu, notari

Johan Palomares, notari

Johan Sanina, notari

Bakers:

Guillem Brelle, forner 


\subsection{List of documents cited in the 1523 inventory}

4.3.1. Accounting documents

\begin{tabular}{|c|c|c|}
\hline $\begin{array}{c}\text { Book / } \\
\text { Document }\end{array}$ & Date & Description recorded in the inventory \\
\hline $\begin{array}{l}\text { Book of receipts } \\
\text { (albarans) }\end{array}$ & $\begin{array}{l}\text { First third } \\
\text { of the } 15^{\text {th }} \text { century }\end{array}$ & $\begin{array}{l}\text { The book began with the coppersmith Dalmau } \\
\text { Palou's debt to Joan Palou. We are reminded } \\
\text { that Dalmau is documented between the years } \\
1433 \text { and } 1434 \text {, which allows us to relate } \\
\text { the accounts to the work of Joan Palou I. } \\
\text { Also recorded are albarans de la casa davant } \\
\text { la capella de·n Marchus ("delivery notes for } \\
\text { the house in front of the Marcùs Chapel"), }\end{array}$ \\
\hline Accounts book & $\begin{array}{l}\text { Start: } 12^{\text {th }} \\
\text { of April, } 1443\end{array}$ & $\begin{array}{l}\text { Joan Palou's name appears, but the } \\
\text { content of the book is not specified. }\end{array}$ \\
\hline Accounts book & $\begin{array}{l}\text { Start: } 6^{\text {th }} \\
\text { of March, } 1449\end{array}$ & The book began with Solà's debt to Joan Palou. \\
\hline Accounts book & $\begin{array}{l}\text { Start: } 23^{\text {rd }} \\
\text { of June, } 1480\end{array}$ & \\
\hline Accounts book & Start: May, 1487 & $\begin{array}{l}\text { The book began with Joan Palou's debt } \\
\text { to Bernat. The date the } 8^{\text {th }} \text { of August is } \\
\text { mentioned, but does not specify the year.. }\end{array}$ \\
\hline $\begin{array}{l}\text { Joan Palou's } \\
\text { accounts book }\end{array}$ & $\begin{array}{l}\text { Start: September, } \\
1497\end{array}$ & $\begin{array}{l}\text { Also mentioned are l'abat de Sent Lorens, } \\
\text { Jofre de Sentmenat y Cortes. The book } \\
\text { had a handwritten piece that read Deu.me } \\
a \cdot m i, \text { Johan Palou, la taula de } \cdot \text { la ciutat. }\end{array}$ \\
\hline Accounts book & $\begin{array}{l}\text { Dated } 10^{\text {th }} \text { of } \\
\text { January, } 1505- \\
4^{\text {th }} \text { of April, } 1516\end{array}$ & $\begin{array}{l}\text { Payments and debts for the sale/purchase } \\
\text { of metals and other concepts. The } \\
\text { inventory transcribes some records: } \\
\text { Doni al Senyer en Pere Vilar per } \\
\text { matalls, pesaven I l[iur] X X onses } \\
\text { Deu lo Senyer en Deia [la]toner } \\
\text { Sia recort a.mi < Gregori> Johan Palou, } \\
\text { courer, que a V de maig de MDXIIII } \\
\text { me fou feta diffinicio de tots drets } \\
\text { Sia recort a.my, Johan Palou, com } \\
\text { havem ensetada la gerra del oli }\end{array}$ \\
\hline Accounts book & No date & $\begin{array}{l}\text { Book headed by red and blue capital } \\
\text { letters that contained the Joan Palou } \\
\text { rubric. Accounts are recorded related to } \\
\text { the corambre and the banc dels hereus. }\end{array}$ \\
\hline
\end{tabular}


4.3.2. Wills and inheritances

\begin{tabular}{|l|l|l|}
\hline \multicolumn{1}{|c|}{$\begin{array}{c}\text { Type of } \\
\text { document }\end{array}$} & \multicolumn{1}{|c|}{ Date } & \multicolumn{1}{|c|}{ Description recorded in the inventory } \\
\hline Will & $\begin{array}{l}26^{\text {th }} \text { of March, } \\
1431\end{array}$ & $\begin{array}{l}\text { Will of Margarida, wife of Pere Palou. This } \\
\text { craftsman could be the one that cast the } \\
\text { Honorata bell of Barcelona Cathedral in 1393. }\end{array}$ \\
\hline Will & $\begin{array}{l}31^{\text {st }} \text { of March, } \\
1431\end{array}$ & $\begin{array}{l}\text { Will of Margarida, muller de Johan Palou. This } \\
\text { most probably refers to Joan Palou I. }\end{array}$ \\
\hline Notarial letter & $\begin{array}{l}28^{\text {th }} \text { of January, } \\
1502\end{array}$ & $\begin{array}{l}\text { Notarised letter from Margarida to her brother, } \\
\text { Joan Palou, regarding los drets e actions que.li } \\
\text { pervenguessen e los bens de aquell. The text specifies } \\
\text { that Margarida was married to the Girona } \\
\text { butcher, Miquel Cassa. }\end{array}$ \\
\hline Inheritance & No date & $\begin{array}{l}\text { Transfer of the inheritance clause of wool carder } \\
\text { Pere Vidal's will. This record appears cited among } \\
\text { the documens regarding the Cases Noves. }\end{array}$ \\
\hline Inheritance & No date & $\begin{array}{l}\text { Transfer of the inheritance clause of Berenguer } \\
\text { Vidal's will. It could refer to the master } \\
\text { bellfounder documented in the year 1423 in the } \\
\text { manual of the notary, Joan Reniu. }{ }^{196} \\
\text { This record appears among the documents } \\
\text { regarding the Cases Noves, along with a receipt of } \\
\text { payment for these houses dated 1408 and signed } \\
\text { by Berenguer Vidal himself. }\end{array}$ \\
\hline
\end{tabular}

\subsubsection{Property}

\begin{tabular}{|l|l|l|}
\hline $\begin{array}{c}\text { Type of } \\
\text { document }\end{array}$ & Date & Description recorded in the inventory \\
\hline \multicolumn{2}{|c|}{ 4.3.3.1. Unidentified houses } \\
\hline Sale & $\begin{array}{l}7^{\text {th }} \text { of November, } \\
1407\end{array}$ & $\begin{array}{l}\text { Sale of houses belonging to the master builder } \\
\text { Jaume Berenguer to the tailor, Joan Torra. }\end{array}$ \\
\hline $\begin{array}{l}\text { Sale and receipt } \\
\text { of payment }\end{array}$ & $9^{\text {th }}$ of June, 1408 & $\begin{array}{l}\text { Letter of ownership de les cases de la dita deffuncta } \\
\text { that the tailor Joan Torra made for matrasser } \\
\text { Marc Julià. }\end{array}$ \\
\hline
\end{tabular}

196. AHPB. Notari Joan Reniu. Manual (1423-1424), f. 17r. 


\begin{tabular}{|c|c|c|}
\hline \multicolumn{3}{|c|}{ 4.3.3.2. Vila Nova Houses (Les Fusines) } \\
\hline Letters & $\begin{array}{l}17^{\text {th }} \text { of March, } \\
1352\end{array}$ & The inventory suggests that they are old letters \\
\hline Sale & $\begin{array}{l}8^{\text {th }} \text { of December, } \\
1396\end{array}$ & $\begin{array}{l}\text { Guillem de Puig, the master bellfounder of } \\
\text { Barcelona, sells the houses of Vila Nova. The } \\
\text { buyer's name is not mentioned. }\end{array}$ \\
\hline Sale & $\begin{array}{l}17^{\text {th }} \text { of June, } 1397 \\
(?)^{197}\end{array}$ & $\begin{array}{l}\text { Bernat Bertran sells the houses mentioned to } \\
\text { Bernat Valor, the master bellfounder. This is } \\
\text { documented as being between } 1407 \text { and } 1409 \text {, } \\
\text { due to the purchase of copper from the merchant } \\
\text { Joan de Junyent. }{ }^{198}\end{array}$ \\
\hline Sale & $\begin{array}{l}8^{\text {th }} \text { of December, } \\
1406\end{array}$ & $\begin{array}{l}\text { Bernat Valor sells the Vila Nova houses to Joan } \\
\text { Palou I }\end{array}$ \\
\hline Sale & Idem. & Ratification of the previous sale \\
\hline $\begin{array}{l}\text { Receipt of } \\
\text { payment }\end{array}$ & 1408 & $\begin{array}{l}\text { Receipt of payment to Berenguer Vidal for the } \\
\text { amount of the stated houses, signed by Guillem } \\
\text { de Puig and el Canon of Barcelona Cathedral, } \\
\text { Pere Ragassol. }\end{array}$ \\
\hline $\begin{array}{l}\text { Carta de procura } \\
\text { ("notarial } \\
\text { letter") }\end{array}$ & $3^{\text {rd }}$ of April, 1413 & $\begin{array}{l}\text { Carta de procura ("notarial letter") for the } \\
\text { houses stipulated in favour of Ginebra, wife of } \\
\text { Barcelona merchant, Federich Bou, carried out } \\
\text { by the canons of the Santa Eulàlia del Camp } \\
\text { monastery. }\end{array}$ \\
\hline Sale & $\begin{array}{l}17^{\text {th }} \text { of March, } \\
1417\end{array}$ & $\begin{array}{l}\text { Ginebra sells the houses of Vila Nova to Joan } \\
\text { Palou I. }\end{array}$ \\
\hline $\begin{array}{l}\text { Receipt of } \\
\text { payment }\end{array}$ & $12^{\text {th }}$ of June, 1417 & $\begin{array}{l}\text { Receipt of payment by Joan Palou of the price of } \\
\text { the houses stated, signed by Ginebra. }\end{array}$ \\
\hline Sale & $\begin{array}{l}4^{\text {th }} \text { of January, } \\
1418\end{array}$ & $\begin{array}{l}\text { Vicenç Çaplana sells one of the Vila Nova houses } \\
\text { to Gerorgi Garriga. }\end{array}$ \\
\hline Letter & $\begin{array}{l}7^{\text {th }} \text { of November, } \\
1474\end{array}$ & $\begin{array}{l}\text { Letter from the obrador de les cases hon mori la } \\
\text { difunta Ginebra. }\end{array}$ \\
\hline Letter & $\begin{array}{l}22^{\text {nd }} \text { of November, } \\
1474\end{array}$ & $\begin{array}{l}3 \text { old letters regarding Ginebra's houses in Vila } \\
\text { Nova. One of them refers to it as l'establiment de } \\
\text { dit obrador. }\end{array}$ \\
\hline
\end{tabular}

197. Possible dating error: despite the fact that the scribe dates the writing in 1497, he himself points out that it is rubricked by the same notary who signed the previous document in 1396.

198. AHPB. Notari Bernat Nadal. Manual $(1407-1408)$, f. $70 \mathrm{v}\left(27^{\text {th }}\right.$ September, 1407$)$ and $f .87\left(4^{\text {th }}\right.$

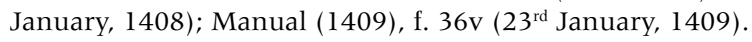




\begin{tabular}{|c|c|c|}
\hline $\begin{array}{l}\text { Carta de procura } \\
\text { ("notarial } \\
\text { letter") }\end{array}$ & $\begin{array}{l}27^{\text {th }} \text { of January, } \\
1475\end{array}$ & $\begin{array}{l}\text { Notarial letter from the Barcelona corrector, } \\
\text { Jaume Forn, to Pere Doms. }\end{array}$ \\
\hline $\begin{array}{l}\text { Carta de procura } \\
\text { ("notarial } \\
\text { letter") }\end{array}$ & $13^{\text {th }}$ of June, 1475 & $\begin{array}{l}\text { Carta de procura ("notarial letter") from Esteve } \\
\text { Doms, Barcelona merchant, to the lawyer Marc } \\
\text { Camps. }\end{array}$ \\
\hline Sale & $\begin{array}{l}8^{\text {th }} \text { of November, } \\
1475\end{array}$ & $\begin{array}{l}\text { The lawyer Marc Camps sells a house to Joan } \\
\text { Palou. }\end{array}$ \\
\hline Deed & $\begin{array}{l}8^{\text {th }} \text { of November, } \\
1475\end{array}$ & Deed for the house cited in Joana Forn's name. \\
\hline $\begin{array}{l}\text { Letter of formal } \\
\text { notice }\end{array}$ & $\begin{array}{l}3^{\text {rd }} \text { of January, } \\
1476\end{array}$ & $\begin{array}{l}\text { Letter from Antoni Fas, cleric procurator of the } \\
\text { canon of Barcelona, Martí Joan de Foxà, and of } \\
\text { the lawyer Marc Camps directed to the afinador } \\
\text { de mides, Gabriel Soler. }\end{array}$ \\
\hline $\begin{array}{l}\text { Carta de procura } \\
\text { ("notarial } \\
\text { letter") }\end{array}$ & No date & $\begin{array}{l}\text { Letter from Martí Joan de Foxà and Marc Camps } \\
\text { regarding the houses of Vila Nova. }\end{array}$ \\
\hline $\begin{array}{l}\text { Letter of } \\
\text { ownership }\end{array}$ & $17^{\text {th }}$ of April, 1476 & $\begin{array}{l}\text { Letter of ownership for the houses of Vila Nova } \\
\text { given by the merchant Esteve Doms to Joan } \\
\text { Palou. }\end{array}$ \\
\hline Letters & $\begin{array}{l}17^{\text {th }} \text { of March, } \\
1352 \text { and } 29^{\text {th }} \\
\text { of March, } 1408\end{array}$ & $\begin{array}{l}\text { The inventory describes them as old letters from } \\
\text { the houses of Vila Nova. }\end{array}$ \\
\hline
\end{tabular}

\subsubsection{Cens for the houses of Vila Nova}

\begin{tabular}{|l|l|l|}
\hline \multicolumn{1}{|c|}{$\begin{array}{c}\text { Type of } \\
\text { document }\end{array}$} & \multicolumn{1}{|c|}{ Date } & \multicolumn{1}{|c|}{ Descripton recorded in the invenntory } \\
\hline $\begin{array}{l}\text { Albarans } \\
\text { ("receipts") }\end{array}$ & $\begin{array}{l}\text { Cens paid for the house of Vila Nova and altres } \\
\text { coses. }\end{array}$ \\
\hline $\begin{array}{l}\text { Albarans } \\
\text { ("receipts") }\end{array}$ & $\begin{array}{l}\text { Last payment: } \\
\text { Christmas of } \\
\text { the year } 1526\end{array}$ & $\begin{array}{l}\text { Cens paid for the house of Vila Nova. The last } \\
\text { payment was of } 27 \text { sous. }\end{array}$ \\
\hline $\begin{array}{l}\text { Albarans } \\
\text { ("receipts") }\end{array}$ & $\begin{array}{l}25^{\text {th }} \text { of August, } \\
1525\end{array}$ & $\begin{array}{l}\text { Cens paid for the house of Vila Nova. In the last } \\
\text { delivery note, for 18 sous, the priest Antoni Martí } \\
\text { is mentioned. }\end{array}$ \\
\hline $\begin{array}{l}\text { Book of Albarans } \\
\text { ("receipts") } \\
\begin{array}{l}\text { Libre dels cens } \\
\text { de la fusina }\end{array}\end{array}$ & $\begin{array}{l}25^{\text {th }} \text { of August, } \\
1525\end{array}$ & $\begin{array}{l}\text { Cens paid for the Vila Nova house. In the last } \\
\text { delivery note, of 9 sous, the canon of Santa } \\
\text { Anna, Jaume Sitjar, is mentioned. }\end{array}$ \\
\hline
\end{tabular}

